\title{
IfIISGUC.ORG
}

"İ̦, GÜç" ENDÜSTRi iLIȘKiLERI VE INSAN KAYNAKLARI DERGISi

"IS, GUC" INDUSTRIAL RELATIONS AND HUMAN RESOURCES JOURNAL

\section{İş Arama Davranışı: Bütüncül Psiko-Sosyal Bir Yaklaşım}

\author{
Job Search Behaviour: \\ An Integrative Psycho-Social Approach
}

\begin{abstract}
Burcu KÜMBÜL GÜLER
Yrd. Doç. Dr., Kocaeli Üniversitesi, İIBF, Çalışma Ekonomisi ve

Endüstri İlişkileri Bölümü
\end{abstract}

Nisan/April 2012, Cilt/Vol: 14, Say1/Num:2, Page: 7-24

ISSN: 1303-2860, DOI: 10.4026/1303-2860.2012.0197.x

Makalenin on-line kopyasına erişmek için:

http://www.isguc.org/?p=article\&id=487\&vol=14\&num=2\&year=2012

To reach the on-line copy of article:

http://www.isguc.org/?p=article\&id=487\&vol=14\&num=2\&year=2012

Makale İçin İletişim/Correspondence to: 
(c) 2000- 2012

“İşGüç” Endüstri İlişkileri ve İnsan Kaynakları Dergisi

"İşGüç" Industrial Relations and Human Resources Journal

\author{
Nisan/April 2012, Cilt/Vol: 14, Say1/Num: 2 \\ ISSN: 1303-2860, DOI: 10.4026/1303-2860.2012.0197.x
}

İş,Güç, Endüstri İlişkileri ve İnsan Kaynakları Dergisi, yılda dört kez yayınlanan hakemli, bilimsel elektronik dergidir. Çalışma hayatına ilişkin makalelere yer verilen derginin temel amacı, belirlenen alanda akademik gelişime ve paylaşıma katkıda bulunmaktadır.

İş, Güç, Endüstri İlişkileri ve İnsan Kaynakları Dergisi, 'Türkçe' ve 'İngilizce' olarak iki dilde makale yayınlanmaktadır. Dergi ulusal ve uluslar arası birçok indekste taranmaktadır. (CABELLS DIRECTORY, EBSCO SOCINDEX , INDEX ISLAMICUS, INDEX COPERNICUS, WORLDWIDE POLİTICAL SCIENCE ABSTRACTS, SOCIOLOGICAL ABSTRACT, ULAKBIM SOSYAL BİLIMLER VERİTANI, ASOS INDEX)

\section{Editör/Editor-in-Chief \\ Aşkın Keser (Uludağ University)}

Editör Yardimcıları/Co-Editors

K.Ahmet Sevimli (Uludă̆ University)

Gözde Yilmaz (Marmara University)

Uygulama/Design

Yusuf Budak (Kocaeli Universtiy)

\section{Tarandiğı Indeksler}

ASOS INDEX

\section{CABELLS DIRECTORY}

EBSCO SOCINDEX

Index ISLAMICUS

Index COPERNICUS

Sociological Abstract

ULAKBİM Sosyal Bilimler Veritanı

Worldwide Political Science Abstracts
Yayın Kurulu / Editorial Board

Dr. Erdem Cam (ÇASGEM)

Dr. Zerrin Firat (Uludă̆ University)

Doç. Dr. Aşkın Keser (Uludağ University)

Prof. Dr. Ahmet Selamoğlu (Kocaeli University)

Yrd. Doç. Dr. Ahmet Sevimli (Uludă̆ University)

Doç. Dr. Abdulkadir Șenkal (Kocaeli University)

Doç. Dr. Gözde Yilmaz (Marmara University)

Dr. Memet Zencirkıran (Uludă̆ University)

Uluslararası Danışma Kurulu / International Advisory Board Prof. Dr. Ronald Burke (York University - CA)

Assoc. Prof. Dr. Glenn Dawes (James Cook University - AU)

Prof. Dr. Jan Dul (Erasmus University - NL)

Prof. Dr. Alev Efendioğlu (University of San Francisco - USA)

Prof. Dr. Adrian Furnham (University College London - UK)

Prof. Dr. Alan Geare (University of Otago - NZ)

Prof. Dr. Ricky Griffin (TAMU-Texas AEM University - USA)

Assoc. Prof. Dr. Diana Lipinskiene (Kaunos University - LT)

Prof. Dr. George Manning (Northern Kentucky University - USA)

Prof. Dr. William L. Murray (University of San Francisco - USA)

Prof. Dr. Mustafa Özbilgin (Brunel University - UK)

Assoc. Prof. Dr. Owen Stanley (James Cook University - AU)

Prof. Dr. Işık Urla Zeytinoğlu (McMaster University - CA)

Ulusal Danışma Kurulu / National Advisory Board

Prof. Dr. Yusuf Alper (Uludă̆ University)

Prof. Dr. Veysel Bozkurt (İstanbul University)

Prof. Dr. Toker Dereli (Işık University)

Prof. Dr. Nihat Erdoğmuş (Şehir University)

Doç. Dr. Mustafa Kurt (Yalova University)

Prof. Dr. Ahmet Makal (Ankara University)

Prof. Dr. Süleyman Özdemir (İstanbul University)

Prof. Dr. Ahmet Selamoğlu (Kocaeli University)

Prof. Dr. Nadir Suğur (Anadolu University)

Prof. Dr. Nursel Telman (Maltepe University)

Prof. Dr. Cavide Uyargil (İstanbul University)

Prof. Dr. Engin Yildirm (Constitutional Court of Turkey)

Doç. Dr. Arzu Wasti (Sabancı University)

Dergide yayınlanan yazılardaki görüşler ve bu konudaki sorumluluk yazarlarma aittir.

Yayınlanan eserlerde yer alan tüm içerik kaynak gösterilmeden kullanılamaz.

All the opinions written in articles are under responsibilities of the outhors.

The published contents in the articles cannot be used without being cited. 


\title{
İş Arama Davranışı: \\ Bütüncül Psiko-Sosyal Bir Yaklaşım
}

\author{
Job Search Behaviour: \\ An Integrative Psycho-Social Approach
}

\author{
Burcu KÜMBÜL GÜLER \\ Yrd. Doç. Dr., Kocaeli Üniversitesi, İIBF, Çalışma Ekonomisi ve \\ Endüstri İlişkileri Bölümü
}

\begin{abstract}
Özet
Genellikle iktisadi açıdan incelenmekte olan iş arama davranışı bu makalede bütüncül olarak psiko-sosyal bir bakış açısıyla incelenmektedir. İstihdam olanaklarının araştırılması olarak ifade edilen iş arama, psikolojik olarak "istihdam amacını gerçekleştirmeye bağh olan ve bununla belirlenen amaçsal ve bireyin kendi iradesine bağglı bir eylem" olarak tanımlanabilir. Günümüzde artan rekabetin sadece firmalar düzeyinde değil, işgücü piyasasında da yaşanıyor olması ve ciddi oranlardaki işsizlik, kendisine uygun iş arayan bireyleri zor durumda bırakmaktadır. Bu koşullarda, iş aramanın ardındaki psiko-sosyal süreci iyi anlayarak iş arayanların isabetli iş arama davranışları gerçekleştirmeleri için onları yönlendirmek ve bu kişilerin iş bulma motivasyonlarını artırarak onlara yardımcı olmak giderek önem kazanmaktadır. İş aramanın psiko-sosyal sürecini anlamak adına yazın taramasıyla birlikte, bütüncül bir model önerisinde bulunan bu makalenin, ülkemizdeki çalışma psikolojisi yazınına katkısının yanı sıra, iş bulma konusunda danışmanlık yapan uygulayıcılar için yol gösterici olması umulmaktadır.
\end{abstract}

Anahtar Kelimeler: İşarama davranışı, Planlanmış Davranış Teorisi, Beklenti-Değer Teorisi, İş arama özyeterliği, İşarama netliği

\begin{abstract}
Job search behaviour, which is usually studied in economic terms, will be investigated in an integrative psycho-social perspective in this study. Simply meaning as a search for employment possibilities, job search can be defined as "a purposive, volitional pattern of action that begins with the identification and commitment to pursuing an employment goal" in psychological terms. Not only the growing competition between companies, but also the competition among work force and significantly high percentages of unemployment put pressure on individuals who seek suitable jobs. Under these circumstances, understanding the psycho-social process behind job search, leading job seekers to well-directed job search behaviours and helping these individuals by enhancing the motivation for job finding have been increasingly crucial. In order to understand the psycho-social process, this study, which benefits from literature review and presents an integrative model, is a considered as a contribution to the work psychology literature in Turkey besides being helpful to the consultants working in the field of job search.
\end{abstract}

Key words: Job search behaviour, Theory of Planned Behaviour, Expectancy-Value Theory, Job search self-efficacy, Job search clarity 


\section{Giriş}

İş arama davranışı daha çok iktisadi bir kavram olarak değerlendirilmiş ve genellikle bu alanda yapılan çalışmaların konusunu oluşturmuştur. Veri setleri üzerinde, ekonometrik analizler yoluyla yapılan çalışmalarda, hükümet politikalarının ve işsiz bireyin iş aramaya yönelik yerine getirmesi beklenen yükümlülüklerin (Keeley ve Robbins, 1985: 355), işsizlik süresinin, rezervasyon ücreti düzeyinin ${ }^{1}$, işsizlik sırasında elde edilen işsizlik sigortası, işgücü piyasası (Başbuğ ve Elgin, 2010: 2) ve aile içi yardımlaşmaların iş aramaya olan etkileri incelenmiştir İktisadi bakış açısıyla iş arama davranışı açıklandığında, iş arayan bireyin işgücü piyasası hakkında tam bir bilgi sahibi olmaması nedeniyle iş arama çabasının belirsizliği üzerinde durulurken, psiko-sosyal bakış açısı, işsiz bireyin iş arama çabası ve etkinliği hakkında öznel düşüncesi olduğunu iddia etmekte (Caliendo vd., 2010: 2) ve iş arama davranışında psiko-sosyal açıdan pek çok faktörün rol oynadığını kabul etmektedir. Dolayısıyla, psiko-sosyal is arama modelinde, iktisadi açıklamalardan başka, başarılı bir is arama ve bulma sürecinde demografik, kişisel ve bilişsel özellikler, çevresel etkenler, sahip olunan sosyal ağ gibi pek çok değişkene yer verilmelidir. Sayılan tüm bu etkenler, iş arayanın diğger aray1ş içinde olanlara göre, işsizlik gibi stresli bir süreçle baş edebilmesinde önem kazanmaktadır (Brown ve Hesketh, 2004: 7). Süreci etkileyen tüm bu faktörleri düşündüğümüzde, iş arama ile ilgili yapılan araştırmaların, hem iş arayan kişi hem de iş aramada danışmanlık görevini üstlenenler için önemli olduğu düşünülmektedir. Dolayısıyla, iş arama davranışında ilerleme kaydedilebilmesi için, psiko-sosyal içerikli araştırma sonuçlarından yararlanılması özellikle önemlidir.

ABD'nin önemli kamuoyu araştırma şirketlerinden biri olan Gallup'un yapmış olduğu bir anketin sonuçları, işsizliğin bireylerin çalışmak istememesinden kaynaklanmadığını, aksine çoğunun istemediğ $i$ bir işte çalışarak eksik istihdam edildiğini göstermektedir. Araştırma sonucunda elde edilen bir bulguya göre, ișsizlerin \% 49'u, eksik istihdam edilenlerin de \% 63'ü dört hafta içinde haftada 30 saat ve üzerinde bir iş bulamayacaklarını ifade etmektedir. Görülüyor ki, isssiz Amerikalıların önemli bir kısmi ümidini kaybetmiş ve iş aramazken, iş arayanlar içinse iş arama, kendi başına bir iş haline gelmiş durumdadir (Unemployed Americans Face Challenging Job Search, 2011). Bu durum ülkemizde Bora vd (2011) tarafından beyaz yakalı işsizler üzerinde yaptıkları araştırmada da ifade edilmektedir: "İşsizler için, iş aramanın kendisi, rutinleri, formları olan, emek verilen bir etkinlik. Aynı zamanda stratejileri olan, bunlar üzerinde düşünülen ve tabi insanın sürekli kendisi üzerine düşünmesine yol açan "girdiler" üreten bir etkinlik" (Bora vd., 2011: 229). Her iki araştırmada da yer alan bu ifadeler iş aramanın önemini açıklar niteliktedir.

Gallup'un ABD'de gerçekleştirdiği bir diğer kamuoyu araştırması ise, uzun süren iş arama sürecinin psikolojik açıdan bireyde yaşattığı olumsuz duygu durumunu yansitmaktadır. Şubat 2011'de açıklanan verilere göre; uzun süredir (11 ay ve üstü) iş arayanların, iş başvurusu yapanların ve iş görüşmesinde bulunanların, tüm bu faaliyetleri daha az zamandır yapanlara göre, daha endişeli, üzüntülü, stresli, öfkeli oldukları görülmekle birlikte, bu bireylere daha fazla depresyon teşhisi konulduğu tespit edilmiştir. Bu bulgulara ek olarak, araştırmanın önemli bir bulgusu ise, iş bulmaya dair umutlu olmanın yaşanılan olumsuz duygu durumunu hafifletici bir etkiye sahip olmasıdır. Ancak 11 ve daha fazla aydır iş arayanların \% 72'si istemedikleri bir işte çalışmak zorunda kalacaklarını ifade etmektedir. \% 58 gibi önemli bir çoğunluğu da önlerindeki dört ay içinde iş bulma beklentilerinin olmadığını belirtmektedir. Dolayısıyla, uzun süreli iş arayanların umut

1 Rezervasyon ücreti, iş arayan bireyin iş teklifini kabul edeceği en az ücret düzeyi olarak bilinmektedir. Bkz. Biçerli, (2000: 417) 
düzeylerinin düşük olması nedeniyle, duygudurumlarının olumsuz etkileneceği ve iş arama davranışı göstermelerinde düşüş yaşanacağ 1 söylenebilir (For Unemployed, Length, Scale of Job Search Affects Wellbeing, 2011).

Görüldüğü gibi, günümüz çalışma yaşamında iş arama, iş değiștirme ve iş bulabilme önemli bir yer tutmaktadır. Böylesi bir gündem içinde, iş aramanın iktisadi boyutu olduğu kadar, iş arama sürecini yaşayan bireyin duygu, düşünce ve davranışlarını etkileyen önemli bir psikolojik sürecin olduğu yadsınamaz. Dolayısıyla günümüzde iş arama sürecinin sadece iktisadi açıdan incelenmesi yetersiz görülmekte, iş aramaya yönelik daha davranışsal ve bireye özgü değerlendirmelerin yapılması gerekliliği anlaşılmaktadır. Günümüzde işsizliğin boyutu büyüdükçe ve işsizlik sırasında yaşanılan duygusal süreçlerin davranışa olan yansımasının ciddiyeti arttıkça, bireylerin psikolojik açıdan iş arama davranışının değerlendirilmesinin önemi giderek artmaktadır. Mezun olduktan sonra ilk defa, iş kaybı nedeniyle ya da sahip olduğu işten memnun olmayıp pek çok defa iş arama deneyimi yaşayan sayısız insan bulunmaktadır. İş arama öylesine yaygın ve sıkça başvurulan bir hale gelmiştir ki, bu süreçte sergilenen davranışlar, bireyin çalışma yaşamının çok önemli bir bölümünü oluşturmaktadir.

Bireyin başarılı bir iş arama süreci geçirip, kendisine uygun olan işte istihdam olanağı bulmasının arkasında yatan nedenleri inceleyen, dünyada oldukça fazla sayıda çalışma bulunmaktadır. Ancak ülkemizde, iş arama davranışı sadece iktisadi boyutuyla incelenmiş, iş arayışı içindeki bireyin psikolojisi genellikle göz ardı edilmiştir. Aslında, iş arama davranışı çalışma psikolojisinin önemli bir konusu olmaya adaydır. Bu makale, çalışma psikolojisi bakış açısıyla iş arama davranışını incelemekte, ülkemiz alanyazınındaki teorik boşluğu giderme amacı taşımaktadır. Makalede öncelikle iş arama davranışı ile ne ifade edildiği, farklı kesimlerin iş arama davranışları ve konunun önemi üzerinde durulacaktır. İş arama davranışına yönelik çeşitli teorik yaklaşımların aktarılmasından sonra, başarılı bir is arama sürecinin öncülleri ve sonuçlarına dair bütüncül psiko-sosyal bir model önerisinde bulunulacaktır.

\section{2. İş Arama Davranışı}

İş bulmanın en önemli unsurlarından birini oluşturan iş arama davranışı, aynı zamanda günümüz çalışma hayatının tamamlayıcı öğelerinden biridir. İș arama, bazen birey herhangi bir işte çalışıyorken yapılabilir ancak genellikle işsiz konumunda olan bireyler tarafından yapılmaktadır (Biçerli, 2000: 414). Yüksek işsizlik oranları, çalışmanın ve işin doğasında yaşanan değişimler, örgütsel yeniden yapılanma ve küçülme gibi nedenlerle, giderek artan sayıda insanın yaşamında iş arama önemli bir yer tutmaktadir (Cote, Saks and Zikic, 2006: 233). İktisadi açıdan baktığımızda, iş arayanların uygun iş olanakları ile buluşturulması amacını güden iş arama süreci, iş aramanın maliyeti ve rezervasyon ücreti gibi ekonomik kıstaslar bağlamında bireyin işi kabul etmesi ve reddetmesi ile ilgilenmektedir. Psiko-sosyal bir bakış açısı ise, bireyin iş aramaya yönlenmesinin arkasındaki motivasyonel nedenlere ilişkin bir değerlendirme yapmaya çalışmaktadır. Bu bölümde, önce is aramanın tanımı üzerinde durulacak olup, işsiz ve çalışanların iş arama davranışı arasindaki farklılıklara değinilecek ve sonrasinda iş aramanın günümüzde neden önemli olduğu üzerinde durulacaktır.

\section{1. İş Aramanın Tanımı}

Basit bir ifadeyle iş arama, istihdam olanaklarının araştırılmasıdır. Daha detaylı bir açıklamayla iş arama, işgücü piyasası alternatifleri hakkında bilgi edinmek için çaba ve zaman harcama yoluyla belirli faaliyetlerde bulunmaktır (Rogelberg, 2007: 414; Bretz vd., 1994: 278). Saks (2004)'a göre, iş arama bireylerin istihdam amacı peşinde olduğu dinamik bir süreçtir. Dahası Saks, iş arama- 
nın amaca yönelik bir davranış olduğunu çünkü hedeflenen amacın gerçekleştirilmesi durumunda iş arama davranışının sona ereceğini ifade etmektedir (Saks, 2005: 157). İş arama davranışının, yukarıda da değinildiği üzere amaç ile bağlantısını vurgulayan Kanfer ve diğerleri (2001) iş aramayı "istihdam amacını gerçekleştirmeye bağlı olan ve bununla belirlenen amaçsal, bireyin iradesine bağlı bir eylem" olarak tanımlamaktadır. Karşılığında da, istihdam amacının gerçekleșebilmesi için tasarlanmış arama davranışının harekete geçtiğini belirtmektedirler. Dolayısıyla araştırmacılar iş bulmada, iş arama davranışını önemli bir belirleyici olarak kabul etmekte ve iş aramayı dinamik, devinimsel, özdüzenleyici bir süreç olarak değerlendirmektedirler (Kanfer vd., 2001: 838).

İş aramanın hangi davranışlardan oluştuğuna dair yazında farklı açılamalar bulunmakta, hangi davranışların iş arama davranışını oluşturduğu konusunda halen bir belirsizlik görülmektedir. İşi olan veya işsiz bireyler hangi davranışta bulunursa, gerçekten iş arıyor olduklarına karar vermemiz gerektiği, detaylı bir şekilde açıklanması gereken önemli bir sorundur. Kanfer ve diğerleri (2001) iş arama davranışlarının boyutlarını şu şekilde açıklamaktadır: a) yoğunluk-çaba (iş arama davranışının sıklık ve gerektirdiği çaba), b) içerik-yön (sergilenen faaliyetler ve bu faaliyetlerin kalitesi), c) geçicilik-kalıcılık (arama davranışının ısrarcı olması ve dinamikliği). Bu boyutlarla ifade edilmek istenen, iş arayan bireyin arama davranışındaki yoğunluğu, hangi davranışları sergilemesi durumunda bu davranışların etkin olup olmadığı ve son olarak bireyin bunu iş buluncaya kadar yapıyor olup olmadiğıdır.

Barber ve diğerleri (1994) ise iş aramayı, iş olanakları hakkında bilgi edinmek, işe ilişkin firsatlar yaratmak, bu firsatlar çerçevesinde değerlendirme ve seçim yapmayı içeren bir süreç olarak tanımlanmaktadır. Fark edilebileceği gibi, Barber vd. (1994) iş arayan bireyi diğer tanımlardan daha aktif bir noktaya yerleştirmekte, fırsat yaratma misyonunu da iş arayana yüklemektedir.

\section{2. İşsiz ve Çalışanların İş Arama Davranışı}

Farklı işgücü kesimlerinden olan bireylerin iş arama davranışı birbirinden farklı olacaktır. Elbette ki, eğitim hayatını tamamlayıp iş aramaya başlamış olan bireyin iş arama davranış şekli, sürecin bitiminde elde edeceği sonuç, işten çıkarılmış veya çalışırken başka bir iş fırsatı peşinde olan bireyden oldukça farklı olacaktır (Rogelberg, 2007: 414). Eğitim sonrası ilk defa iş arayan ya da işten çıkarılmış olanların aslında temelde buluştukları nokta "işsiz olmak"tır. Bu nedenle her iki kategoride bulunan bireylerin iş arama davranışı göstermelerinin asıl nedeni, bir istihdam olanağ yakalamaktır (Rogelberg, 2007: 414). İlk defa iş arayanlar, eğitim hayatından iș hayatına adım atanlar olmaktadır. İs arama özellikle bu grup için oldukça önemlidir çünkü işgücüne ilk defa katılan bu bireylerin seçecekleri ve istihdam edilecekleri ilk işin onların gelecekteki kariyerine ve gelirine büyük etkisi vardır. Günümüzde hem eğitim alanında hem de işgücü piyasasında yaşanan küresel çaptaki hareketlilik sayesinde artan rekabet, iş aramayı ilk defa iş arayanlar için daha önemli hale getirmektedir (Wilson, 2007: 2)

İş arama çabasında, bireylerin kendisini diğer işsiz bireylerle kıyaslaması rol oynamaktadır (Mavridis, 2010: 3). Bu kişiler genellikle halihazırda çalışanlar olmakla birlikte, işgücü piyasası içinde işsizlerin konumu ve motivasyonu, bu kişilerin iş aramalarına etki etmektedir. Ancak bu kesimin iş arama davranışlarının altında yatan neden, hiç kuşkusuz işsizlerin nedenlerinden farklı olmaktadır. İşsiz birey için herhangi bir iş bulmanın başarılı olarak değerlendirilmesi, gizli işsiz konumundaki çalışan birey için başarılı bir iş arama süreci çıktısı olmayabilir. Çalışmakta olan bireyin herhangi bir iş fırsatı elde etmesinden çok, iş arama davranışı içine girmesinin ardında, 
farklı motivasyon ve beklentiler bulunabilir. Örneğin, birlikte çalıştığı işverenine piyasada aranan biri olduğunu göstermek ya da işindeki sosyal ağı genişletme imkanı elde etmek iş arama davranışını tetikleyen faktörler olarak düşünülebilir (Rogelberg, 2007: 414). Ayrıca, işi olan bireyin iş arama davranışında; psikolojik sermayenin ${ }^{2}$ güçlü olması ters yönlü bir etkide bulunmaktadır (Avey vd., 2009: 686). Bu durumda, psikolojik sermaye halihazırda iş sahibi olanlarda iş arama davranışı üzerinde olumsuz bir etkiye sahipken, işsizlerin iş aramasına olumlu katkıda bulunan bir yapı olarak düşünülebilir. Bu nedenle, işsiz birey ile işi olan bireyin sahip olduğu özellik ve deneyimlerin iş arama davranışına farklı şekilde yansıması kaçınılmazdır.

İş aramaya yönelik iktisadi modellerin geliştirildiği çalışmaların yapıldığı ilk dönemlerde, çalışmakta olan bireylerin iş arama davranışına yönelmeyeceğ $i$, iş aramanın sadece işsiz olan bireylere özgü olduğuna dair bir anlayış hakimdi (Burdett, 1978: 212). Ancak günümüzde, sahip olduğu işten memnun olmayan, iş ve birey uyumunun sağlanmadığı, bireyin eğitim düzeyinden daha düşük düzeyde vasıf gerektiren işte çalışıyor olmak olarak özetlenebilecek eksik istihdam durumunda olan pek çok çalışan bulunmaktadır. Bu kişiler daha iyi bir iş buldukları anda, çalıştıkları işten ayrılma eğiliminde olup, iş arama davranışları, işsiz olanlardan farklı gerçekleşebilmektedir. Nitekim araştırmalar da bu düşünceyi desteklemektedir. Örneğin Feldman ve Turnley (1995) eksik istihdam edildiğini düşünen üniversite mezunlarının, düşünmeyenlere göre, işe yönelik daha olumsuz tutumlara sahip olduğu ve daha fazla iş arama davranışı içine girdiği ya da bir yıl içinde iş arama niyetlerinin olduğunu görmüşlerdir. Araştırmacılar aynı zamanda işyerlerindeki kü- çülme nedeniyle işten çıkarılmış ve kendilerinin eksik istihdam edildiğini düşündürten işlerde yeniden çalışmaya başlamış olan bireylerin, daha düşük iş doyumuna sahip olup, yeniden çalışmaya başladıktan sonra bile iş arama davranışı içinde bulunduklarını görmüşlerdir (Aktaran Erdogan ve Bauer, 2011: 216). Eksik istihdam edilen bireylerin yeniden işe yerleştirme danışmanlığ1 (outplacament) alıp iş arama davranışı içine girmesinde yükleme teorisi bağlaminda açıklama getirmek mümkündür. $\mathrm{Bu}$ bireylerin, içinde bulunduğu durumu çok ciddi görmeyip, durumu tersine çevirebileceğini ve durumun bir ölçüde de olsa kendi kontrolleri altında olduğunu düşünmeleri mümkündür. Bu durumdaki bireyler, iş bulmada danışmanlık hizmetlerinden yararlanıp, kariyerlerinin yörüngelerini değiştirmelerini sağlayacak iş arama davranışları gösterebilirler (Feldman, 2011: 300).

Çalışanlar arasında iş arama davranışını motive edecek bir diğer faktör, iş güvencesizliği algısı olarak düşünülebilir. İş güvencesizliği algısını, bireyin kendi isteği dışında iş kaybı olasılığının öznel bir değerlendirilmesi olarak düşünmek mümkündür. Kavram, sahip olunan işin devamına yönelik potansiyel bir tehdit algılayışı olarak tanımlanabilir (Sverke vd., 2002: 243). Bireyin iş güvencesizliği algısının yüksek olması, yeni bir iş arama yoluyla işten ayrılma niyetini belirlemektedir. Çünkü işini güvencesiz bulan birey, daha güvenceli, alternatif bir iş bulmak ümidiyle, yeni iş olanakları aramaya başlamaktadır. Dolayısıyla bireyin iş güvencesizliği algısının yüksek olması, iş arama yoğunluğunu artırmaktadır. Özellikle istihdam edilebilirliği daha olası olan bireylerin iş arama davranışı gösterme yoluyla tepkide bulunmaları olasılı̆̆ yüksektir (Çakır, 2007: 134; King, 2000: 79).

2 Pozitif psikolojik sermaye, “1) mücadele gerektiren görevleri başarmak için gerekli çabayı sarf edebileceğine dair kendine güven duyma (özyeterlik), 2) şu anda ve gelecekte başarılı olacağına dair olumlu yüklemede bulunma (iyimserlik), 3) başarmak için amaçlara giden yolda ssrar etmek ve gerekli olduğunda amaçlara giden yolları değiștirebilmek (umut), 4) sorun ve zorluklarla karşılaşınca başarılı olabilmek için güçlü durmak ve kendini toparlayabilmek (dayanıklılık) özellikleriyle açıklanabilen bireyin gelişimine dair olumlu psikolojik durum" olarak tanımlanmaktadır. Konu hakkında daha detaylı bilgi için bkz. Kümbül-Güler (2009: 119-146). 


\section{3. İş Arama Davranışının Günümüzdeki Önemi}

İş arama, çalışma çağındaki nüfusun giderek artan sıklıkta gerçekleştirdiği bir eylem haline gelmiştir. Çalışma yaşamının büyük bir dönüşüm içinde olduğu bilinmektedir. Küresel rekabetin etkisiyle, işletmelerin maliyetlerini kısma arzuları daha esnek bir yapıyı gerekli kılmaya başlamıştır. Esnek işgücü piyasası artan oranda güvencesizliği de beraberinde getirmiştir. Artan işsizlik ve eksik istihdamla birleşince istihdam olanaklarının azlığ 1 daha net anlaşılmaktadır. Görülüyor ki, iyi ya da uygun iş olarak da nitelendirebileceğimiz formel işler günümüzde ciddi bir azalma içindedir. Her yıl giderek daha fazla sayıda insan, işten çıkarıldı̆̆ 1 için, ilk defa işgücü piyasasına dahil olduğu için, stajını tamamlayıp kariyer arayışı içine girdiği için ya da var olan işinden memnun olmayıp yeni bir iş ve kariyer olanağ 1 peşinde olduğu için iş arama davranışı sergilemektedir. Bu durumun ileride çalışma yaşındaki tüm insanlar arasında küresel bir savaşa dönüşme olasılığ maktadır (Kanfer vd., 2001: 837). Dünyadaki 7 milyar insanın 5 milyarı 15 ve daha üzeri yaşta olup bu insanların 3 milyarı, Gallup araştırma verilerine göre, çalışmakta ya da çalışmak istemektedir. Bu durum çok ciddi bir soruna yol açmaktadır çünkü tüm dünyada, formel yapıda sadece 1,2 milyar iş bulunmaktadır (Clifton, 2011: 1). Öyleyse, dünyada iş yaratılamama sorunu gündeme gelmektedir ki, bu da iş arama ve bulmanın günümüzde ne kadar önemli olduğunu açıkça göstermektedir.

İş arama davranışının araştırılmasının ülkemiz için önemi üzerinde durmak gerekirse, öncelikle genç işsizliği oranlarına atıfta bulunmak gerekmektedir. Bilindiği üzere, genç işsizliği Türkiye'de önemli bir sorundur. Aralık 2011'e ait TÜİK verileri dikkate alındığında, 15-24 yaş arası gençlerde işsizlik oranının \% 18,8 olduğunu görmekteyiz. Bu durum üniversite mezunu olan gençlerde daha yüksek olup, \% 24 ile ciddi bir oranı temsil etmektedir ${ }^{3}$. Genç işsizliğine yönelik bu olumsuz tablonun arka planında, elbette ülkede iş yaratamama sorunu olduğu gibi, isabetli bir iş arama davranışı gösterememe de bir etken olarak düşünülebilir.

Günümüz sorunlarından uzun süreli işsizlik de iş arama davranışını olumsuz etkileyebilecek bir faktördür. Yapılan bir çalışmada, iş arama süresinin uzamasıyla birlikte, özellikle yaşlı kesimde iş arama davranışının belirleyicilerinden biri olan iş arama sıklığında önemli düzeyde bir azalma saptanmıştır. Araştırmacıların bu konudaki önerisi, danışmanlar aracılığıyla, işsiz bireyde iş sahibi olmanın avantaj ve firsatlarına odaklanarak, iş arama sürecinin özendirilmeye çalışılmasıdır (De Coen, vd. 2011: 26). Çünkü, aktif bir şekilde iş arama, yeniden bir iş bulmanın önemli bir belirleyicisidir (McKee-Ryan vd., 2005: 58). Elbette ki bu öneri, uzun süreli iş arayıp da bulamamış olan küskünlerin işgücü piyasasına geri çağrılması açısından da isabetli bir uygulama olacaktır.

\section{Teorik Açıdan İş Arama Davranışı}

İş arama davranışının nasıl oluştuğuna, bireyin iş arama davranışı göstermesinde etkili olan faktörleri anlamaya ve açıklama çalişan bu bölümde, öncelikle psikoloji yazınında önemli yer tutan "Planlanmış Davranış Teorisi" ve "Beklenti-Değer Teorisi" ile giriş yapılacaktır. Sonrasında, bu teorilerden de yararlanılarak, iş arama davranışı konusunda oluşturulan model önerileri üzerinde durulacaktır.

\section{1. İş Arama Davranışını Açıklamaya Ya- rayan Teoriler}

Bu bölümde davranışı oluşturan önemli bir öğe olan niyet konusuna odaklanan Plan-

3 Oldukça güncel bir yayın olan Bora vd. (2011)'nin “Boşuna mı Okuduk?” adlı eserleri, yüksek öğrenim sahibi işsizlerin içinde bulunduğu durumu "beyaz yakalı işsizlik" olarak ifade etmektedir. Eserde, işsiz ve son sınıf üniversite öğrencileri ile yapılan nitel bir çalışmanın sonuçları aktarılmaktadır. İşsizliğin psiko-sosyal sürecine odaklanan bu eser, ülkemizde diploma sahibi olan vasıflı işsizliğin boyutunun giderek arttığını ifade ederek yaşanılan deneyimi, işsizliği yaşayan bireylerin ağzından aktarmaktadır. 
lanmış Davranış Teorisi ve hedefin gerçekleşmesinde, hedefe verilen değer ve bireyin bunu yapabilir görmesinin önemini gösteren Beklenti-Değer Teorisi'nin, kısaca iş arama davranışını açıklama şekli üzerinde durulacaktır.

\subsubsection{Planlanmış Davranış Teorisi}

Planlanmış Davranış Teorisi (PDT)'ye göre, kişiler davranışlarının sonucu hakkinda önceden düşünürler, seçtikleri bir sonuca ulaşmak için karar verirler ve bu kararı uygularlar. Dolayısıyla, bireyin davranışını belirleyen, doğrudan bireyin o davranışa yönelik tutumu değil, niyetidir. Kısacası tutum niyeti, niyet de davranışı etkiler (Kağıtçıbaşı, 1999: 115). Teoriyi geliştiren Ajzen'e göre, bireyin bir davranışta bulunmasının en önemli belirleyicisi davranışa yönelik niyettir. Niyete etkide bulunan 3 unsur bulunmaktadır: 1)kişinin davranışa yönelik tutumu (davranış ile birlikte belirli sonuçların elde edileceğine dair inanç), 2)öznel değerler (davranışı gerçekleştirmek ya da gerçekleştirmemek adına çevreden gelen sosyal baskı algıs1), 3)fark edilen davranışsal kontrol (ki bu durum algilanan özyeterlik ile ilgilidir) (Zikic ve Saks, 2009: 120).

Teorinin iş arama davranışını açıklamak için kullanılması durumunda, iş arama davranışı sonuçta bireyin sergilediği davranış olmaktadır. İş arama davranışının gerçekleşmesi için önemli olan niyet ise iş arama niyeti olarak ifade edilebilir. Niyete etki eden unsurlardan tutum, teoriye göre, bireyin iş aramaya dair bilişsel ve duygusal değerlendirmesini içermektedir. Bazı kişilerin iş bulmak için sarf edilen çabayı gereksiz ve sıkıntılı bulurken, bazılarının bunun yararlı, gerekli ve duygusal olarak zevkli olabileceğini düşünmesi tutum konusuna örnek olarak verilebilir. İkinci unsur olan öznel değerler, bireyin çevresindeki insanların onun iş bulması için çaba sarf etmesini ne kadar beklediklerine dair inancını ifade et- mektedir. Son olarak fark edilen davranışsal kontrolde ise, iş arama özyeterliği olarak ifade edilebilecek olan bir unsur bulunmaktadır ki, bu da bireyin iş bulmak için yapılması gereken belli davranışları başarılı bir şekilde yürütebileceğine dair inancını temsil etmektedir (Başbuğ, 2008: 38-39). Örneğin, bireyin uygun bir başvuru mektubu yazabileceğine dair kendine güveni, bir iş ilanına başvurmak için bir davranışta bulunma eğilimini güçlendirmektedir (Van Hooft vd., 2004: 368).

\subsubsection{Beklenti-Değer Teorisi}

Feather (1992) insan davranışını açıklamaya yönelik bir teori olan Beklenti-Değer Teorisi'ni iş arama davranışını açıklamak için de kullanmıştır. Bu teoriye göre davranış, davranışın sonucuyla ilgili beklentiye ve bireyin sonuca ilişkin atfettiği değere göre belirlenmektedir. Teoriye göre, iş aramak için motive olmak ve yoğun bir şekilde iş arama davranışında bulunulması için, bireyin iş bulabileceğine dair bir beklentisinin olması ve aynı zamanda iş bulmaya değer vermesi gerekmektedir. Bir diğer ifadeyle, bireyin işe alınması konusundaki beklentisi ve iş bulmayı ne kadar cazip gördüğü iş arama istekliliğini artıracaktır. Dolayısıyla beklenti ve elde edilecek olan sonuca verilen önem bireyin gelecekteki istihdam durumun belirleyen önemli bir faktördür (Başbuğ ve Elgin, 2010: 5).

Feather (1990) aynı zamanda, pek çok başarısız iş arama ve bulma girişiminden sonra, iş bulma beklentisinin düşeceğini ve istenilen işin birey için değerinin kaybolacağını ifade ederek, işsizlerin iş arama yoğunluğunu ve kullandıkları metotları azaltacaklarından bahsetmektedir. Feather, bu durumun tekrarlanan başarısız iş bulma girişimleri sonucu gerçekleşen öğrenilmiş çaresizlik ${ }^{4}$ ile ilişkili olduğunu ifade etmektedir (aktaran Bjornstadt, 2006: 461). Aslında Beklenti-Değer teorisinin öğrenilmiş çare-

4 Öğrenilmiş çaresizlik, ardı ardına yaşanan başarısızlıklar sonucu, bireyin gelecekte başarılı olabileceğine dair ümidini kaybetmesi, çabalamak adına herhangi bir motivasyona sahip olmaması ve bunlara eşlik eden depresif ruh hali olarak tanımlanabilir. İşsizlikte öğrenilmiş çaresizlik oluşumu ile ilgili olarak bkz. Kümbül-Güler (2005). 
sizliğin tersi bir tepki doğurabileceğine dair açıklamaları da vardır. Bu konuda, teorinin kapsadığı bir diğer yaklaşım Brehm'in "Tepki Teorisi" dir". Bu teoriye göre, ardı ardına is bulma girișimlerinde başarısız olan bireyin; is bulma gereksinimi ne kadar fazlaysa, işsizliğin etkisi ne kadar genişse, iş bulmak ne kadar önemliyse ve birey iş bulma konusunda kendine ne kadar fazla güveniyorsa, iş arama davranışı artış gösterecektir ${ }^{6}$. Dolayısıyla tepki teorisine göre, başarısız iş arama girişimleri olan bireyin öğrenilmiş çaresizlik geliştirip, iş aramaktan uzaklaşması yerine, tersine bir tepki geliştirerek, iș arama davranışlarını artırması söz konusu olmaktadır.

\section{2. İş Arama Davranışı Konusunda Oluştu- rulan Teorik Modeller}

Psikoloji yazınında önemli olan PDT ve Beklenti-Değer Teorisinin, iş arama davranışına yönelik genel açıklamalarından sonra, bu bölüm iş arama davranışına özgü geliştirilmiş modelleri sunmaktadır.

\subsection{Soelberg'in Genellenmis Karar Süreci} Modeli

İş arama davranışı konusunda doktora tezi hazırlamış olan Soelberg (1967)'e göre iş arama dört aşamadan oluşmaktadır. 1) İstenilen işin tanımlanması, 2) aramanın planlanması, 3) işin aranması ve seçilmesi ve son olarak 4) kararın doğrulanması ve alınan karara bağlllık göstermek. İlk aşama olan işin tanımlanmasında, birey aktif bir şekilde iş aramaya başlamadan önce, kendisi için ideal işi belirlemeye çalışmaktadır. Burada bireyin aklında kendine ait "kişisel değerler" ve seçeceği işe yönelik "algılanan iş özellikleri"ni içinde barındıran yazılı olmayan bir liste bulunmaktadır (Power ve Aldag, 1985: 49). İkinci aşama olan aramanın planlanmasında, birey, karşısında çıkan ilk iş seçenekleri hak- kında bilgi sahibi olmasına yarayacak zaman, çaba, para kaynaklarını araştırır ve bulur ${ }^{7}$. İşin aranmaya başlaması ve işin seçilmesini içeren üçüncü aşamada, birey istihdamda aracı hizmetleri kullanarak, çevresindeki insanlara sorarak, iş aramaya yardımcı olan mekanizmalardan destek almaya başlamaktadır. Formel olarak iş arama sürecine kendini adamasıyla başlayan bu süreç, bireyin kesin bir iș seçmesi ve artık bir diğer yeni iş alternatifi ile ilgilenmemesine kadar devam etmektedir. Son aşama olan kararın doğrulanmasında ise, birey seçmiş olduğu işe bağlanmakta ve işe yönelik seçimi hakkındaki bilgiyi doğrulamaktadır. Teklifte iyileştirme yapma yönündeki görüşmelerden sonra birey, daha iyi bir teklifle karşılaşmayacağını düşünüyorsa, seçimine bağlanarak, çevresindekilere seçimi ile ilgili duyuruyu yapar.

\subsubsection{Blau Modeli}

Blau (1993) Soelberg'in iş arama sürecinden etkilenmiştir. Blau'nun getirdiği yenilik, iş arama davranışında hazırlık aşaması ve aktif iş arama sürecini birbirinden ayırarak, daha rahat uygulanabilir bir yaklaşım sunmasıdır. İş aramaya hazırlık adını verdiği ilk etapta Blau, arzu edilen seçeneklerin varolup olmadığının araştırıldığını ifade eder. Bunu yaparken arkadaşlar veya akrabalarla olası pozisyonlar hakkında konuşmak, gazete, dergi veya profesyonel bir dernek veya internetteki iş ilanlarını okumak gibi davranışlar üzerinde durur. İkinci aşama olan aktif is aramada ise, hazırlık aşamasında incelenmiş olan seçeneklerin birey için gerçek anlamdaki uygunluğu belirlenmeye çabalanır. $\mathrm{Bu}$ aşamada ise, bireyin olası işverene özgeçmişini göndermesi, bir istihdam arac1lığ̣ yapan şirket ya da iş kurumu ile görüşmesi söz konusudur. Araştırmalar göstermektedir ki, hazırlık aşaması ve aktif

5 Tepki Teorisi, bireyin özgür davranışlarından bir veya birkaçının tehdit edilmesi veya elinden alınması durumunda, sözü edilen özgürlüğün tekrar kazanılması için, bireyde karşıt bir kuvvet oluşturan motivasyonu açıklamaya çalışmaktadır.

6 Bu açıklamalar, Brehm'in “Tepki Teorisi” bağlamında, bireyin kontrol edilemez durumla karşılaşması halinde, vereceği tepkiler doğrultusunda yapılmıştır. Ayrıntılı bilgi için bkz. Kümbül-Güler (2006: 11-14).

7 Süreçteki bu aşama, bir bakıma ileride Blau Modeli'nde açıklanacak olan iş aramaya hazırlı̆̆ı içerir. 
iş arama birbiriyle ilişkili ancak birbirinden bağımsız boyutlar olup, farklı öncül ve sonuçlara sahiptir. Örneğin, iş aramaya hazırlik aktif iş aramanın öncülü iken, aktif iş arama, pozisyon seçimi ile ilgili kararları daha güçlü bir şekilde belirlemektedir (Blau, 1993: 326; Rogelberg, 2007: 414). Bunlardan farklı olarak Blau ayrıca, iş arama çabasına da önem vermektedir. İş arama çabası, bireyin iş ararken zaman ve enerji sarfetmesini içeren bir boyut olarak göze çarpmaktadır. Benzer şekilde, Kanfer ve diğerleri (2001) de, işe sahip olabilmek için, bireyin iş ararken kişisel kaynaklar olarak zaman, çaba ve sosyal ağ kullanımı gibi sosyal kaynaklardan yararlandıklarını ifade etmektedir.

\subsubsection{Barber ve diğgerlerinin İş Arama Modeli}

Barber ve diğerleri (1994) Soelberg ve Blau'nun modellerinden de esinlenerek üç ayrı başlık altında, iş arama davranışındaki değişimi sırasıyla şu modeller üzerinden öne sürmüştür: Sırasal düzen modeli, öğrenme modeli, duygusal model. Tüm bu modellerde, yazarların özellikle üstünde durdukları iki değişken bulunmaktadır. Bu değişkenlerden biri, iş arama süresince kullanılan kaynak olup, arkadaş ve akraba gibi enformel kaynakları ve iş bulma kurumu, aracı kurumlar gibi formel kaynakları içermektedir. Diğer değişken ise, iş arama yoğunluğudur ve iş ararken bireyin 1 srarc1 olmasını ve çaba sarfetmesini konu edinmektedir.

Barber vd. (1994)'nin “sırasal düzen modeli" özellikle zamana vurgu yaptığı için, sürece ilişkin yaklaşım bağlaminda önemlidir. Yazarlar, bu model kapsamında, iş arayan bireylerin sirayla farklı ve sistematik bir şekilde iş arama faaliyetlerinde değişiklik yaptığını vurgulamaktadırlar. Daha önce de bahsedildiği gibi Blau, Soelberg'den esinlenen ve ayrica Rees (1966)'in kapsamlı ve yoğun iş arama faaliyetlerine atıfta bulunan yazarlar, iş arayanların geniş bir yelpaze ile başlayıp olasılıkları giderek daralttığını ifade etmektedirler (Barber vd, 1994: 742). Süreç itibariyle önemli bir diğer model olan öğrenme modelinde ise, iş arama süresi art- tıkça, adayların daha verimli ve etkin arama teknikleri kullanmaya başlayacağı ifade edilmektedir. İş arama süreci boyunca, iş arayanların kişisel deneyimleri sayesinde, diğer iş arayanların başarılarını gözlemleyerek ya da iş arama yazınını takip ederek bilgilerini artırdığı düşünülmektedir (Barber vd, 1994: 745). Son olarak, duygusal modelde ise, daha çok bilişsel bir mekanizmanın hakim olduğu diğer iki modelden farklı olarak iş arama süreci dahilindeki duygusal tepkiler konu edilmektedir. Modelde, iş arayan bireyin işverenler tarafindan reddedilerek kendisini psikolojik açıdan rahatsız hissetmesi, iş arama süresinin de uzamasıyla birlikte, zaten stresli olan bu durumun daha stresli hale gelmesi konu edilmektedir. Bu süreçte yaşanan reddedilme deneyimlerinin bireyi öğrenilmiş çaresizliğe sürükleyeceği, özgüven ve özyeterliğini olumsuz etkileyeceği ve buna bağlı olarak iş aramadaki motivasyonu düşüreceği ifade edilmektedir (Barber vd, 1994: 746).

Yazarlar, iş arama yoğunluğunun sırasal düzen ve duygusal modelde azalacağını, öğrenme modelinde ise artacağına tahmin etmişler, ilk varsayımları kabul edilmiş ancak öğrenme modelinde, iş arama yoğunluğunun artmadığı görülmüştür. Kaynak kullanıminda ise, sirasal ve öğrenme modellerinde zaman geçtikçe daha az formel ve daha fazla enformel kaynak kullanıldı̆̆ varsayılmış ve bu varsayım kısmen desteklenmiştir. Duygusal modelde ise, zamanla daha az enformel kaynak kullanılacağ 1 tahmin edilmiş ancak bu varsayım desteklenmemiştir (Barber vd, 1994: 747).

\subsubsection{Wanberg ve diğgerlerinin İs Arama Sü-} recindeki Günlük Tereddüt Modeli

Wanberg ve diğerlerinin (2010) özdüzenleme teorisinden yararlanarak oluşturdukları bu kavramsal model, bireyin iş arama sürecinde günlük olarak davranışlarında tereddütler oluştuğunu iddia etmektedir. İş arama sürecinin inişli çıkışlı ve günlük değişimler gösteren bir süreç olduğundan hareketle, araştırmacilar modelde, durum bazlı duygulara önem vermişlerdir. 
Modele göre, bireyin bir gün iş arama sürecinde ilerleme kaydedemediğini düşünmesinin, ertesi gün olumsuz bir duygu durum içine girmesine ve iş bulmaya ilişkin güveninin azalmasina etkisi bulunmaktadir (Wanberg vd., 2010: 801).

Modele katkıda bulunan özdüzenleme teorisi, duyguların, göreve ilişkin çabanın ve aynı zamanda amacın gerçekleşmesine yönelik tepki ve başarı algısının bireysel olarak düzenlenmesini anlatmaktadır. İș arama süreci özdüzenleyici bir süreç olarak değerlendirilebilir, çünkü iş arayan bireyin duygu, düşünce ve davranışlarını yeni bir iş bulabilme amacıyla düzenlemesi sözkonusudur. Zaman içinde, iş arama davranışı, çevreden gelen iş fırsatları ve arama stratejileri gibi özdüzenleyici bileşenlere geribildirimde bulunarak, yön ve yoğunluk açısından değişim gösterebilir (Kanfer vd., 2001: 838). Özdüzenleme teorisine göre, hedefteki algılanan ilerleme, duygu durumunu ve hedefin başarılmasına yönelik özyeterliği etkilemektedir. Bir diğer ifadeyle, birey hedefe yönelik ilerleme kaydettiğini düşünüyorsa, olumlu bir duygu durum içine girecek ve hedefi gerçekleştireceğine dair yeterliliği artacaktır.

Bu durumu iş arama sürecine uyarlamak gerekirse, Şekil 1'den takip edilebileceği üzere, iş arama konusunda ilerleme gösterdiğini düşünen birey, yeni bir iş bulma konusunda kendi yetkinliğine olan inancını artıracaktır. Elbette ki burada, BeklentiDeğer teorisinde de olduğu gibi, iş bulmak olan hedefin birey için önemi (bireyin içinde bulunduğu finansal zorluk ve iş bulma konusuna kendisini adaması) etkili olmaktadır. İş bulmaya yönelik bir ilerleme kaydettiğini düşünen, yine Beklenti-Değer Teorisi'ne göre beklentisi artış gösteren ve iş bulmaya değer veren birey, iş aramayla ilgili olarak daha fazla zaman ve çaba harcayacaktır. Araştırmacılar, iş arama sürecinin özerk, reddedilme ve belirsizlik ile baş edilmesi gereken bir süreç olduğunu, dolayısıyla bireyin kendi kendini güdülemesine ihtiyaç duyulduğundan, özdüzenleyici yeteneklerin devreye girdiğini ifade etmektedir.

\subsubsection{Zikic ve Saks'ın İs Arama Modeli}

Zikic ve Saks'ın (2009) iş arama modeli, Sosyal Biliş ve Planlanmış Davranış Teorisi'ni (PDT) içermektedir. Sosyal biliș teorisi, bireyin psiko-sosyal işlevselliğini; davranış, bilişsel ve diğer kişisel faktörler ile çevredeki olayların etkileşimiyle açıklamaktadır. Bu üç faktör, Bandura'nın “üçlü karşılıklı neden-

\section{Şekil 1}

Wanberg ve diğerlerinin (2010) İş Arama Sürecine İlişkin Kavramsal Modeli

Gün X

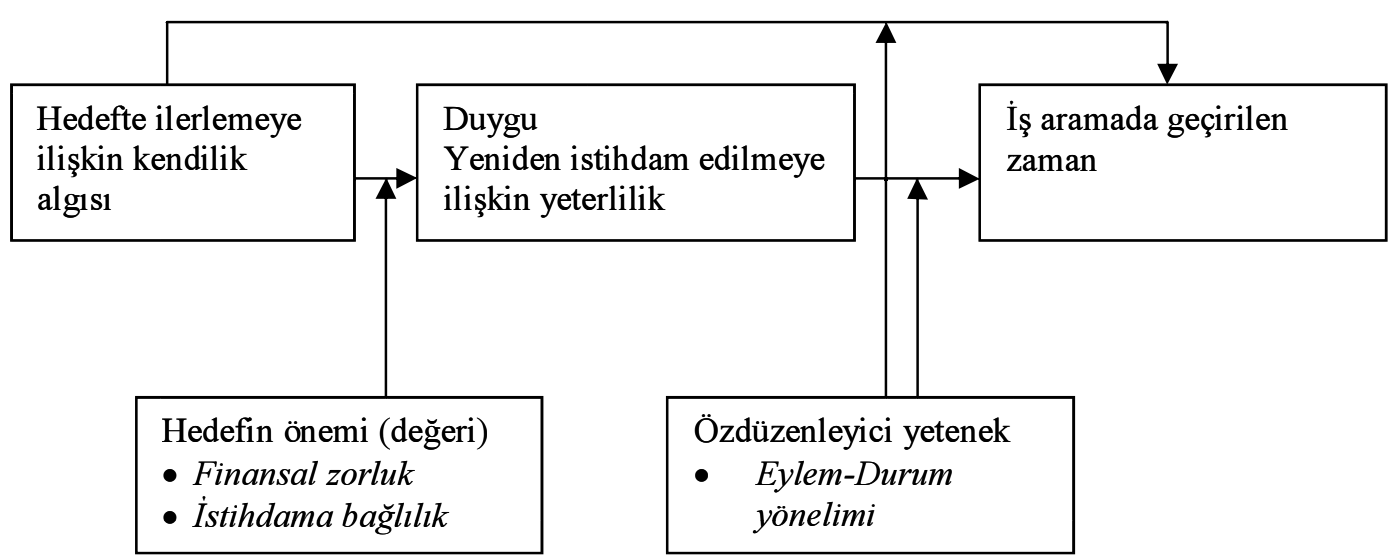

Kaynak: Wanberg ve diğerleri (2010: 789) 
sellik" süreci içinde birbirlerini etkilemektedir (Zikic ve Saks, 2009: 118). Teoriye göre, bireyler içsel dürtülerle ya da çevresel unsurlarla tepki vermekten çok, kendi kendini programlayabilen, proaktif ve özdüzenleme yeteneğine sahip organizmalar olup kendi düşünce, duygu ve davranışlarının yeterliliğini değerlendirebilmektedirler (Doğan ve Şahin, 2011: 69). Dolayısıyla teorinin içeriğinde özyeterlik ve hedef gibi, iş aramada önemli olan bileşenler bulunmaktadır. Bu bileşenler aynı zamanda, çevresel faktör olarak düşünülebilecek kariyer ile ilgili faaliyetlerden de etkilenmektedir. Zikic ve Saks (2009), daha önce bahsedilmiş olan PDT'nin unsurlarını da modele dahil etmişlerdir. Bu teoride araştırmacılar, öznel değerlerin çevresel, tutum ve özyeterliğin bilişsel ve kişisel, iş arama niyetinin hedefe yönelik olma ve son olarak davranışın da iş arama yoğunluğu olarak ele alınabileceğini öne sürmektedirler (Bkz. Şekil 2).

Şekli yorumlamak gerekirse, araştırmacılar kariyer keşfini kariyere ilişkin bilgi edinme; kariyer kaynaklarını bireyin kariyer seçimi konusunda yardım aldığı danışmanlık, kariyer merkezi gibi yerler olarak; eğitimi ise kariyerde yeni beceri edinme şeklinde ifade etmektedir. Şekilde görül- düğü üzere, araştırmacılar kariyere ilişkin sözü edilen faaliyetlerin iş arama netliği ve özyeterliği olumlu etkileyeceğini beklemektedirler. PDT bağlaminda da, iş arama özyeterliği, iş aramaya yönelik tutum ve öznel değerler, niyeti etkileyerek, davranış olarak iş arama yoğunluğunu olumlu etkilemektedir (Zikic ve Saks, 2009: 118).

\section{4. İş Arama Davranışının Öncül ve Sonuçlarına İlişkin Bütüncül Bir Model Önerisi}

İş arama davranışının öncülleri olarak, bireylerin başarılı bir şekilde sonuçlanan iş arama davranışı sergilemelerine neden olan faktörlerden bahsedilmektedir. İş aramada öncül faktörlerin belirlenmesiyle, iş aramaya etki eden psikolojik ve sosyal faktörlerin anlaşılması mümkün olmakta ve böylelikle iş arama çabasında bireye destek olunabilecek yöntemler ortaya çıkarılmaya çalışılmaktadır. İş arama davranışının sonuçları ise, bireyin istihdam edilip, iş doyumu elde etmesi veya memnuniyetsizlik sonucu işten ayrilma eğilimi içinde olmasına kadar uzayabilen bir süreci kapsamaktadır. Bu modelde, sadece iş aramanın ilk etaptaki çıtıları ve istihdam edilmeye kadar olan süreç değerlendirilecektir. Belirtmek gerekir ki, model işsizler

\section{Şekil 2}

Sosyal Biliş Teorisi ve Planlanmış Davranış Teorisi Etkileşimli İş Arama Davranışı Modeli

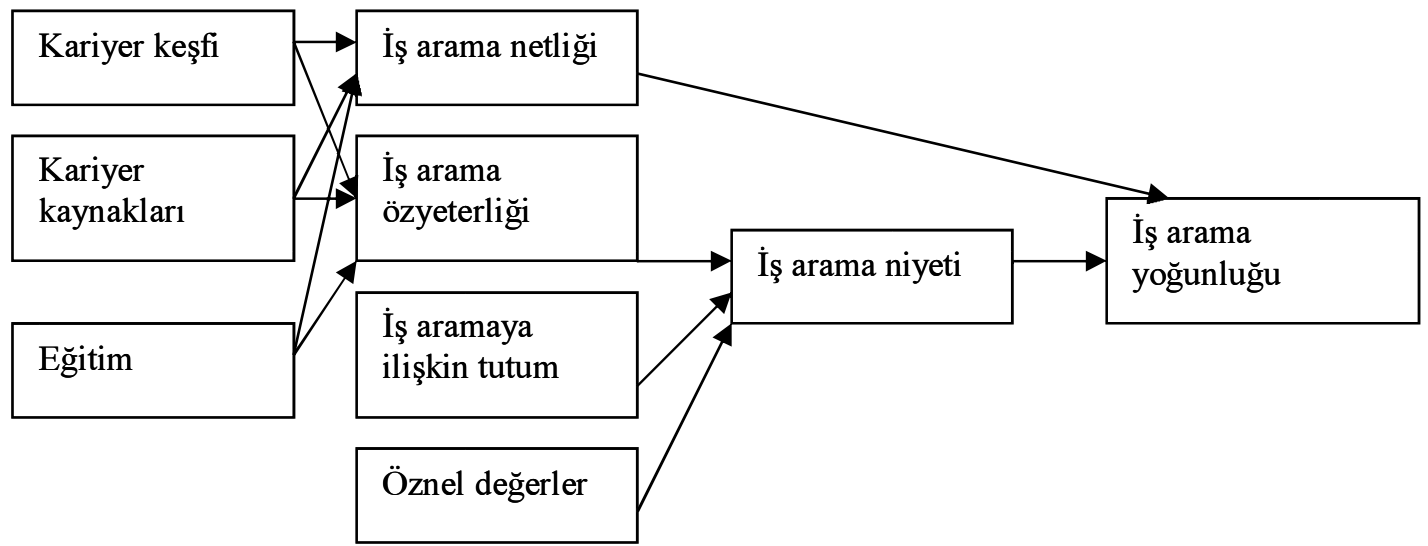

Kaynak: Zikic ve Saks (2009: 118) 
ve/veya çalışanlara özgü, belirli bir gruba özel olarak önerilmemiş, her iki grubu da içerecek şekilde iş arayan bireyi etkileyen faktörlerle, iş arama davranışının sonuçları arasında bağlantı kurulmaya çalışılmaktadır. Öne sürülen model, çalışmanın sonunda yer alan ekteki şekilde görülebilir.

\section{1. İş Arama Davranışının Öncülleri}

Ekteki şekilden görülebileceği üzere, iş arama davranışının öncülleri olarak demografik özellikler, bireysel özellikler ve diş koşullar bağlamında çeşitli faktörlere yer verilmiștir. Modelde sosyal biliș teorisinden esinlenerek davranıș, bilişsel ve diğer kişisel faktörler ile çevredeki olayların etkileşimini içeren bir bakış açısı bulunmaktadır. Öncüllerin birbirleri ile etkileşim halinde olduğu ve etkilemekte olduğu faktörler şekil üzerinde belirtilmiştir.

\subsubsection{Demografik Özellikler}

İș arama davranışını şekillendireceği düşünülen cinsiyet, yaş, eğitim ve kıdem önemli faktörler olarak görülmektedir. İstihdamda cinsiyete bağlı olarak yaşanan farkl1lıklar, iş arama sürecinde de kendini göstermekte, kadın ve erkeklerin iş arama davranışları birbirinden farklı olabilmektedir. Demografik değişkenlerin iş arama davranışı üzerindeki etkilerini inceleyen bir çalışmada, erkeklerin iş aramayı kadınlara göre daha önce düşünmeye başladıkları, işe alımla ilgili gecikmelerde erkeklerin kadınlara göre daha fazla örgütsel özelliklere atıfta bulundukları, yine işe alımda yaşanan gecikmeden erkeklerin kadınların göre daha fazla olumsuz etkilendikleri sonuçları elde edilmiştir (Rynes ve diğerleri, 1990: 53). Tüm bu bulguları değerlendirdiğimizde, belki de gelir elde etmenin öncelikli olarak kendisinden beklenildiği erkeklerin, kadınlara göre, iş aramayı daha önemli ve değer verilen bir süreç olarak algılaması mümkündür.

Yaş, istihdamda önemli bir kıstas olmakla birlikte, yaşlı çalışanlar çalışma yaşamının önemli bir kesimini oluşturmaktadır. Dolayısıyla iş arama davranışında da yaş faktö- rünün önemli bir rol oynadiğg düşünülmektedir. Wanberg ve diğerleri (1996), yaş ile iş arama sıklığının iş bulma üzerindeki etkisi ile ilgili olarak, yaşlı bireylerin gençlere göre is arama sıklıklarının iş bulmada daha az etkili olduğunu görmüşlerdir. Yaş kıdem ile de ilişkilidir. Kıdem de, iş arama davranışının yine en önemli belirleyicilerinden olup, burada yine yaş gibi tersine bir ilişki sözkonusudur. Kıdem arttıkça, bireyin iş arama davranışında bir azalma görülmektedir (Rogelberg, 2007: 414). Artan otomasyon ve bilgisayarlaşmanın etkisinin özellikle orta yaştan başlamak üzere yaşlı çalışanlara doğru, bireylerin kendilerini ve deneyimlerini değersiz olarak algılamalarına neden olduğu görülmektedir (Bora vd., 2011: 68). Bu durumdaki bireyin, iş arama davranışının azalacağı düşünülebilir.

İş arama davranışına etkide bulunabilecek bir diğer demografik faktör eğitim düzeyidir. Buna göre, bireyin eğitim düzeyi ne kadar yüksekse, iş arama davranışı göstermesi o kadar olasıdır (Rogelberg, 2007: 414; Kanfer ve Hulin, 1985). Ayrıca, eğitim düzeyi yüksek olan bireylerin iş arama sürecine daha çok zaman harcama eğiliminde olduğu görülmektedir (Van Hooft vd., 2004: 378).

\subsubsection{Bireysel Özellikler}

Bireysel özellikler başlığı altında, iş arayan bireyin kişilik yapısının yanı sıra, özgüven ve özyeterlik gibi bilişsel özelliklerin ve içinde bulunulan duygusal durumun iș aramaya yönelik özyeterlik ve tutumu etkileyerek iş arama niyeti ve sonrasında iş arama davranışlarının oluşmasında etkili olacağ düşünülmektedir.

\subsubsection{Kişilik Yapısı}

Bireyin kișisel özelliklerini içeren kişilik yapısının iş arama davranışı üzerinde etkili olduğu bilinmektedir. Bu konudaki önemli bir değişken olan Büyük Beş kişilik özelliklerinin durum bazlı olmak üzere işsizlik üzerinde etkili olduğu sonucuna ulaşmıştır. Wanberg ve diğerleri (2000) dişadönüklük ve sorumluluğun sosyal ağlara katılım gösterme ve geleneksel iş arama yöntemleri kul- 
lanma ile ilişkili olduğu sonucunu elde etmiştir. Schmit ve diğerleri de (1993) sorumluluk ve açık sözlülügün verimli etkin iş arama davranışı ile arasındaki ilişkinin olumlu olduğu, nevrotizm ile iş arama davranışı arasında da negatif bir ilişki olduğu sonucunu elde etmişlerdir. Yakın zamanda yapılmış bir çalışmaya göre de, nevrotizm boyutunda düşük puanların ve sorumluluk boyutunda yüksek puanların iş teklifi almada ve işi elde tutmada önemli belirleyiciler olduğu bulunmuştur (Uysal ve Pohlmeier, 2010: 22). Nevrotizm, sorun çözmede başarısız olmak, bağımlı bir karar verme stiline sahip olmak ve kariyerde kararsız kalmak ile ilişkisi olması nedeniyle (Kanfer vd., 2001: 839) iş aramayı olumsuz etkileyen bir kişilik faktör olarak karşımıza çıkmaktadır.

Israrcı olma özelliğinin iş arama davranışını olumlu etkilediği ifade edilmektedir. İşverenlerin iş arayanlarda, iş olanakları hakkında görüşmek istediğini bildirmek, iş başvurusunun ne durumda olduğunu öğrenmek için 1srarlı bir şekilde aramak, işletme istemese dahi iş ile ilgili ek bilgi sunmak gibi içinde 1srarcılığ 1 barındıran bir kişilik yapısının başarılı bir iş arama sürecine katkıda bulunduğu görülmektedir (Schmit vd., 1993: 107).

Kişilik yapısında proaktif olmak olarak bilinen özelliğin iş arama davranışına etkisi olduğu varsayılmaktadır. Proaktif kişiliğin dayandığ1 varsayım bireyin çevreyi, çevrenin de bireyi sürekli olarak etkilediğidir. Böylelikle birey "çevrenin baskısını kabul eden pasif bir alıcı" olmaktansa, varlık gösterdiği çevreye etkisi olan aktif bir organizmadır. Bu durumda, proaktif kişiliği "çevresel değişimi etkilemek adına göreli sabit eğilim" olarak belirtmek mümkündür (Brown vd., 2006: 718). Proaktif kişilik ile ilgili çalışmalarında, Brown ve diğerleri (2006) bu kişilik özelliğine sahip olanların daha fazla istihdam olanağına sahip olduklarını ve bu kişilerin sadece işlerinden memnun olmakla kalmayıp kendi tercih ve değerleriyle uyumlu olan işyerlerini seçmekte de başarılı oldukları sonucunu elde etmişlerdir.

İş arama davranışını etkileyebilecek bir diğer kişilik özelliği dayanıklılıktır. Psikolojik sermaye boyutlarından biri olarak günümüzde oldukça fazla üzerinde durulan dayanıklılık, aşırı stres ve sıkıntı gibi zorlu durumlar karşısında, durumun üstesinden gelebilme veya duruma uyum sağlayabilme yeteneği olarak ifade edilmektedir (Holaday ve McPhearson, 1997: 348). Fleig-Palmer ve diğerleri (2009) dayanıklılık içerikli önerdikleri modellerinde, bu kişilik yapısının başarısızlığ1 başarıya dönüştürdüğ ü düşüncesinden hareketle, bireyde dayanıklılığın geliştirilmesinin, karşısına çıkan engellere rağmen, iş aramada yeniden istihdam edilmede başarı sağlamada etkili olacağını öne sürmektedirler.

Kişilik yapısı içinde düşünülebilecek kontrol odağının da iş arama davranışında etkili olduğu ifade edilmektedir. Kontrolün ne kadar kişinin kendisinden ya da dış etkenlerden kaynaklandığını ifade etmek için kullanılan kontrol odağı, içsel veya dişsal olarak ikiye ayrılmaktadır (Kümbül-Güler, 2006: 52). Yapilan bir çalışmada, içsel kontrol odağına sahip olan bireylerin iş arama için yapacakları yatırımların karşılığını işe girdiklerinde alacaklarına inandıkları görülmüştür. Ayrıca, yaşamlarındaki olaylar hakkında kontrol sahibi olduklarını düşünen bu bireylerin, diğerlerine göre, iş ararken belirledikleri rezervasyon ücretinin daha yüksek olduğu ve daha yoğun bir şekilde iş aradıkları görülmüştür (Caliendo vd., 2010: 16-17).

\subsubsection{2. Özdeğerlendirme Değişkenleri}

Bir işe sahip olmak için gerekli nesnel özellikleri ve becerilerinin yansıra, başarılı bir iş ve birey eşleşmesi yaşanması için, bireyin iş arama sürecine ilişkin yeterli olma durumuna dair yarg1 ve beklentileri de önem kazanmaktadır. Bu bölümde, özdeğerlendirme değişkenleri başlığı altında özyeterlik ve özgüvene değinilecektir.

Bireyin yeterlik algısı etkin bir iş arama sürecinde ve iş bulmada önemli bir belirle- 
yendir (Wanberg, 1999). Bandura (1997) özyeterliği bireyin belirli performans düzeylerine ulaşmasını sağlamada gerekli olan eylemleri düzenleyip uygulayabilmek için yetkinliğine dair yargıları içeren inanç olarak tanımlamaktadır. Özyeterliği yüksek olan bireyin yapacağ ${ }_{1}$ işlerde başarılı olacağına dair inancı yüksek olacağ konusunda da başarılı olmayı beklemesi nedeniyle daha yoğun bir çaba göstereceği düşünülebilir. Özyeterlik, aynı zamanda görev odaklı bir yapı olduğu için, is arama özyeterliğinden de bahsedilmekte, bu konuya aracı değişkenler altında ayrıca yer verilmektedir.

Bir diğer özdeğerlendirme değişkeni olan özgüvenin de iș arama sürecinde etkili olması beklenmektedir. İşsizlik bireyin kendilik algısına zarar veren bir süreç olduğundan, işsizliğin uzaması özgüvenin azalmasına neden olmaktadır (Goldsmith vd., 1996: 333). Bu durum, 150 görüşmeyi içeren bir araştırma tarafından da desteklenmiş; tipik bir işsiz bireyin, zaman geçtikçe iş bulmakta kendine daha az güvendiği ve dolayısıyla daha az istihdam edilebilir hale geldiği görülmüştür. Bireyin işsiz geçen 9 ay sonrasında işsizlik yaşantısına alıştığı, kendini işsizlikten kurtarmaya dair inancını yitirdiği (Bjornstad, 2006: 462) ve dolayısıyla iş arama davranışlarının azaldığı söylenebilir. Sahip olunan özgüven düzeyinin de bir özdeğerlendirme değişkeni olarak iş arama davranışında etkili olacağı varsayılmaktadır.

\subsubsection{Duygusal Durum}

Bireyin içinde bulunduğu duygusal durum iş arama sürecinde etkili bir faktördür. İş arama süreci sıkıntı içeren bir süreç olduğundan, duygusal durum bu süreçten önemli ölçüde etkilenmektedir. Özellikle, işini kaybetmiş olan bireylerin, olayın yaşandığ 1 anda mutluluk düzeylerinde ciddi bir azalma yaşanmaktadır. Ancak, sonrasında işsiz olan diğer bireylerle etrafı sarılan bireyin mutluluk düzeyinde küçük bir artış meydana gelmektedir ve bu durum "sosyal norm" olarak bilinmektedir. Sosyal normun etkisiyle, işsizlik oranının artış göstermesi ile birlikte, mutluluk düzeylerinde artış gözlenen bireylerin daha az iş arama davranışına girmesi söz konusu olmaktadır. Kısacası, bu açıklamaya göre, işten ayrılma sonrasında yoğun bir şekilde iş arayan bireyin çabası giderek azalmaktadır (Mavridis, 2010: 1).

İşsizliğin iş arama davranışını azalttığına dair farklı bir açıklama ise McKee-Ryan ve diğerlerinden (2005) gelmektedir. Yazarlara göre, bireyin işsiz kalmasının olumsuz etkisi, çevredeki işsizlik oranının yüksek olmasıyla daha vahim hale gelmektedir. İşsizliğin yaygin olduğu düşüncesi içindeki işsiz birey, iş bulamayacağına dair endişesiyle birlikte zihinsel ve psikolojik açıdan kendini kötü hissedecek ve daha az iş arama davranışı gösterecektir. Dolayısıyla bireyin yeniden işe girme olasılığı azalacaktır.

Duygusal durumun önemli belirleyicilerinden biri olan psikolojik sağlığın düşük düzeyde olması iş bulmaya olumsuz etkide bulunabilmektedir. Yüksek düzeyde sıkıntı ve endișe içinde bulunan bireyler, aktif bir şekilde is aramaya dair zaman ve enerjileri olmaması nedeniyle iş bulmakta sorun yaşayabilmektedir. Cote ve diğerleri (2006) iş arama davranışında olumlu duygulanımın, olumsuz duygulanımdan daha etkili olduğunu ifade ettikleri, üniversite öğrencileri üzerinde yaptıkları çalışmada, olumlu duygu duruma sahip olanların bilişsel açıdan iş aramada zihinlerinin daha net olup, bunun da iş arama davranışını olumlu etkilediği sonucuna ulaşmışlardır. Ancak bazen, önemli bir duygusal durum belirleyicisi olan ve korku, öfke, üzüntü gibi olumsuz duyguları içeren olumsuz duygulanımın iş arama sürecinde, bireyin iş arama motivasyonunu artırdığı da ifade edilmektedir. Dolayısıyla, olumsuz duygulanımin, hem bireyin motivasyonu olumsuz etkileyerek iş arama başarısını düşürmesi hem de iş arayanların istihdam hedeflerini düşük düzeyde tutarak işe girmeyi kolaylaştırması nedeniyle çift rolü olduğu dile getirilmektedir (Crossley ve Stanton, 2005: 558). 


\subsubsection{Dıș Koșullar}

Bu bölümde, iş arayan bireyin arama sürecinde yararlandığı sosyal ağın önemi, bireyin içinde bulunduğu finansal durumun etkisi ve bireyin iş arama sonucu elde edeceği kariyerine ilişkin bilgi arayışı içinde olması, bilgi kaynaklarını kullanması gibi kariyeri ile ilgili uğraş içinde olduğu faaliyetler üzerinde durulmaktadır.

\subsubsection{1. İş Aramada Sosyal A $\breve{g}$ Kullanımı}

"Kimi tanıdığınız" 1 ifade eden sosyal ağ, bireyin işgücü piyasasında olan işler hakkında bilgiye ulaşmasına aracılık eden önemli bir yapıdır. Daha önce Blau'un iş arama davranışı açıklamalarında da görüldüğü üzere, iş arama yöntemlerine, bireyin olası işler hakkında çevresindeki kişilerle konuşması ve onlarla fikir alışverişi yapması dahil olmaktadır.

Sosyal ağ oluşturma davranışı, bireylerin işlerinde veya kariyerlerinde kendilerine yardımcı olabileceğini düşündüğü potansiyel kişilerle ilişki kurma ve sürdürme olarak tanımlanabilir. Bu davranışı iş arama süreciyle bütünleşik olarak düşünmek gerekirse, sosyal ağ kullanımını, iş arayan kişinin iş bulmakla ilgili bilgi almak, yönlendirmek ya da tavsiyede bulunmak için yararlanabileceği arkadaş, tanıdık ve diğer bireylerle ilişki kurmaya yönlenmiş bireysel eylemler olarak belirtmek mümkündür (Wanberg, 2000: 492). İş ararken sosyal ağdan yararlanmanın iş arama davranışına olumlu yansıması beklenmektedir. Nitekim Green ve diğerlerinin (2011) araştırmasında da görüldüğü gibi, yoğun bir şekilde sosyal ağ kullanımı iş arayan bireyin istihdam edilme şansını artırmaktadır. Çalışmada ayrıca, diğerlerine göre daha önce iş bulmuş olan kişilerin, işlerini arkadaş, aile, önceki iş arkadaşı veya sosyal ağ yoluyla bulduklarını daha fazla ifade ettikleri görülmüştür. Van Hoye ve diğerlerinin (2009) çalışması da, iş aramada kullanılan sosyal ağın iş teklifi sayısı ile pozitif yönlü, ancak işteki statüyle negatif yönlü ilişkili olduğunu göstermektedir. Günümüzde iş bulmaya yönelik internet üze- rindeki sitelerin iş ilanlarını arkadaşlarına yönlendirmeyi giderek daha fazla öneriyor olması da sosyal çevrenin ne kadar etkili olduğunu göstermektedir (Van Hoye vd., 2009: 678).

Sosyal sermaye sahibi olmanın önemi hakkında ülkemizde yapılan bir çalışma olan Başbuğ'un (2008) araştırmasında da, iş teklifi sayısının yapılan iş görüşmesinden daha fazla gerçekleşmiş olmasının sebebi araştırıldı ğında, ișverenlerin adayı hiç tanımadan, güvendikleri kişilerin referansı yoluyla adaya doğrudan iş teklifinde bulundukları görülmüştür. Bu durumu Başbuğ (2008) ülkemizde kişisel bağlantıların iş bulmada etkili bir araç olduğunu ifade ederek, öğrencilerin daha öğrencilik yıllarında sahip oldukları sosyal ağı geliştirmeleri için çabalamalarının önemli olduğunu belirtmektedir.

\subsubsection{Finansal Zorluk}

Finansal zorluk, bireyin iktisadi açıdan s1kınt1 yaşama ölçüsüdür (Kanfer vd., 2001: 841). Finansal açıdan sıkıntı içinde olma durumu iş arama davranışında rol oynayacağ 1 düşünülen önemli bir faktördür. Finansal açıdan zor bir durumda olan bireyin iş araması bir zorunluluk olup, iş arama sürecinde başarı sağlayamama olumsuz duygulanıma neden olmaktadır. Bu durumun iş arama özyeterliğini olumsuz etkilemesi söz konusu olabilir (Wanberg vd., 2010: 790). Dolay1sıyla, finansal açıdan ciddi sorumlulukları olan ve bunları karşılayacak yeterli kaynağa sahip olmayan bireylerin bir is bulup bu kaynağ1 karşılamaya yönelik ihtiyacı daha fazla olmaktadır (Kanfer vd., 2011: 841). Bu nedenle, finansal zorluğun iş arama davranışını daha fazla artıracağı düşünülse de, elde edilen işin bireyi ne kadar memnun edeceği konusu belirsizdir.

\subsubsection{Kariyerle ilgili Faaliyetler}

Kariyerle ilgili faaliyetler, bireyin seçeceği kariyeri keşfetmesi, kariyer kaynaklarından yararlanmayı içermektedir. Günümüzde, güvencesizlik ve sık işten çıkarmaların yoğun olarak yaşanmasıyla birlikte sürekli 
olarak değişen işlere sahip olan bireylerin işgücü piyasasındaki işler ve kariyer olanakları hakkında bilgi sahibi olması gerekmektedir. Bireyin, işten çıkarılma anında veya memnuniyetsizlik nedeniyle işten ayrılması durumunda, yeniden işe girme şansını artırabilmesi için özdüzenleme becerilerini geliştirmesinde, kariyere ilişkin faaliyetlerde bulunması özellikle önemli görülmektedir (Koen vd., 2010: 128). Kariyer keşfi, bireyin yapmak istediği iş tipi, kariyeri hakkında bilgi edinmek adına seçenekleri keşfetmesi olarak tanımlanabilir. Yaşam boyu sürmesi mümkün olan bu keşfin, iş arayanlar için başarılı bir iş aramada ilk adım olduğu öne sürülmektedir (Zikic ve Saks, 2009: 119; Koen vd. 2010: 129). İş arayan bireylerin iş aramaya başlamadan önce, olası işler hakkında bilgi alınabilecek kaynaklar olan kariyer fuarı, kariyer merkezi, mesleki danışmanlık ve hatta devletin iş bulma kurumu danışmanlığı gibi çeşitli olanaklardan yararlanması ise kariyer kaynaklarını kullanmak olarak ifade edilmektedir (Zikic ve Saks, 2009: 120). Bu kaynakların kullanımı, bireyin iș arama netliğine sahip olmasına neden olacaktır ve böylece bireyin iş bulma olanağı elde etmesi kolaylaşacaktır.

\subsection{Aracı Değişkenler}

Bu bölümde, daha önce teorik açıklamalarda da yer verildiği için, ayrı ayrı değişkenler üzerinde açıklama yapılması gerekli görülmemektedir. Ancak modeldeki etkileşimi aktarmak adına değişkenler hakkında kısaca bilgi verilip aralarındaki etkileşim varsayımları üzerinde durulacaktır. Aracı değişkenlerin yer aldığı bu bölümde, Planlanmış Davranış Teorisi'nden yararlanılmaktadır. Buna göre, iş arama özyeterliği, iş aramaya yönelik tutum ve öznel değerlerin bireyde iş arama niyeti oluşturmasıyla birlikte iş aramaya yönelik bir davranışın sergilenmesi öngörülmektedir. $\quad \mathrm{Bu}$ değişkenlerin dışında, bireyin açık hedeflere sahip olmasının önemini belirten iş arama netliği de yazında sıkça aracı değișken olarak kullanılan bir faktör olduğu için, kavrama burada yer verilmesi uygun görülmüştür.

Aracı değişkenlerden önemli bir tanesi, iş arama özyeterliğidir. Bireysel özellikler altındaki algısal özelliklerde de belirtildiği gibi, özyeterlik genel olarak düşünülebilir. Buradaki kavram ise, daha spesifik ve belirli bir görev olan iş aramaya yönelik olup, bireyin istenilen istihdam sonucunu elde edebilmesi için gerekli olan davranışları yapabileceğine dair inancı ifade etmektedir (Moynihan et al., 2003: 208; Saks, 2004). Dolayısıyla, güçlü bir iş arama özyeterliğine sahip olan birey, ilgisini tümüyle iş aramaya yöneltecek, is arama yöntemlerini uygulamak için uğraş verecek, iş arama sürecinde kendine güvenecek ve olumsuzluklarla karşılaştığında ise yılmayacaktır. İş arama özyeterliği içinde düşünülebilecek tüm bu bilișsel hazırlıklar iş görüşmesi için davet alıp is bulmada etkili olmaktadır (Steffy vd., 1988: 255). Kanfer ve Hulin (1985) araştırmalarında iş arama özyeterliği ile genel iş arama davranışı arasında ilişki bulmuşlar fakat iş arama özyeterliği ile başvurulan iş sayısı arasında bir ilişki saptayamamışlardır. İş arama özyeterliği, Planlanmış Davranış Teorisi çerçevesinde, fark edilen davranışsal kontrol olarak düşünülebilir.

İş aramaya yönelik tutum, bireyin iş aramanın kendisine sağlayacağ olumlu ya da olumsuz olmasinı ifade ettiğinden, iş arama niyetinin gerçekleşmesinde önemli bir faktördür. Bireyin iş aramayı, elde etmek istediği nihai hedef doğrultusunda kendisi için akıllıca ve yararlı bulmasının yanı sıra, iş arama davranışını ilginç ve eğlenceli bulmak gibi duygusal öğeleri konusunda da olumlu olması iş arama tutumunu güçlü k1lacaktır (Van Hooft vd., 2004: 385). Ayrıca, daha önce teoriler kısmında ele alınan Beklenti-Değer Teorisi'ne atfen, iș aramaya bireyin değer vermesinin, bunun kendisi için önemli olduğunu düşünmesinin iş aramaya yönelik tutumu güçlendirmesi beklenmektedir.

Bireyin yaşamında önem verdiği diğer kişilerin iş arama ve bulma konusundaki değer yargılarını ve bunlara bireyin inanma 
düzeyini belirten öznel değerler de iş arama niyeti ve sonrasında iş arama davranışının oluşmasında etkili olabilir. Kültüre göre farklılık göstereceği düşünülen bu değişken konusunda, toplulukçu kültürlerde, tutumdan çok öznel değerlerin niyet ve davranışı öngörmesi beklenmektedir. Toplulukçu bir kültüre sahip olan ülkemizde üniversiteden mezun olmakta olan gençler üzerinde yaptığ1 araştırmasında Başbuğ (2008) da benzer sonuçlar elde etmiş, gençlerin iş arama niyetlerinde, kendilerinin iş aramaya yönelik tutumlarından çok anne, baba, arkadaş ya da çevrelerindeki diğer insanların düşüncelerinin etkili olduğu sonucuna ulaşmıştır. Dolayısıyla modelde, öznel normun sosyal ağ kullanımını, finansal zorluğu ve ayrıca kariyere ilişkin faaliyetlerde diğer bireylerin görüşlerinden etkilenmeyi içinde barındıran diş etkenlerden etkilenerek iş arama niyetini açıklaması beklenmektedir.

İş arama netliği, iş arayanın iş aramaya ilişkin hedeflerinde ve ne tür bir iş istediği konusunda ne kadar açık olduğunu ifade eden ve iş arama yoğunluğunu belirleyen bir faktördür (Van Hoye ve Saks, 2008: 359). Kanfer ve diğerleri (2001), amaçlı bir eylem olan iş arama davranışının başarılı olması için amacın belirli ve net olmasının önemli olduğunu belirtmektedir. Dolayısıyla, açık bir kariyer hedefi olan bireyin, aktif iş arama davranışlarında bulunup, yoğun bir şekilde iş araması sayesinde iş bulmada daha başarilı olması beklenmektedir.

\subsection{Davranıs}

Blau (1993)'nun daha önce bahsedilmiş olan modelinin benimsendiği bu bölümde, iş arama davranışı "iş aramaya hazırlık" ve "aktif iş arama olarak" ele alınmıştır. Buna ek olarak, yine Blau ve diğer araştırmacılar tarafından da sıklıkla önerilen "iş arama yoğunluğu / çabası"na yer verilmiştir.

İş aramaya hazırlık davranışları arasında; gazete ve dergide iş ilanlarını okumak, özgeçmiş hazırlamak/gözden geçirmek, iş bulmak ya da iş değiştirmek için bir kitap ya da makale okumak, olası iş yönlendirmeleri hakkında arkadaş ya da akrabalarla konuşmak, potansiyel is olanakları hakkında eski işveren ya da iş ile ilgili tanıdıklarla konuşmak gibi eylemler bulunmaktadır. Yanı sıra, aktif iş arama davranışları içinde; herhangi bir gazete ya da dergide kendini potansiyel aday olarak göstermek, potansiyel bir işverene özgeçmiş göndermek, bir iş başvurusu doldurmak, muhtemel bir işverenle iş görüşmesi yapmak ve bir istihdam bürosu ya da iş kurumu ile iletişime geçmek gibi eylemlere yer verilmektedir. Günümüzde ise farklı olarak, internet kullanımının yoğunluğunu da hesaba kattığımızda, internetin iş arama davranışını etkilemesi kaçınılmazdır. Bu nedenle, internet üzerinde iş aramak ve iş arama siteleri ya da işverenlerin erişim sayfalarını ziyaret etmek de iş arama davranışı arasinda sayılmaktadir. Bunun da eklenmesiyle birlikte, Van Hoye ve diğerleri (2009) iş arama davranışlarını; basılı ilanlarda, internette, kamu istihdam hizmetlerinde ve sosyal ağda iş aramak gibi dört ayrı sınıflandırmada değerlendirmiştir.

İş arama davranışını ölçerken, Kanfer ve diğerlerinin (2001) daha önce bahsedilmiş olan boyutlarından yoğunluk-çaba ile ilişkili olarak, iş arama sıklığ (yoğunluğu) önemli bir ölçüt olarak değerlendirilmektedir (Saks, 2005; Feather ve O'Brien, 1987). S1klık, enerji ve zaman harcamayı da içerecek şekilde Blau (1993)'nun iş arama davranışı ölçeğinde yer almaktadır: "Herhangi bir iş alternatifi için oldukça fazla zaman harcama", "iş aramak için büyük çaba sarfetmek". Kanfer ve diğerlerinin (2001) meta-analitik çalıșmasında, iş arama ve çabasının istihdamdaki başarı ilişkili olduğu görülmüştür. Yoğun bir şekilde iş arama davranışı gösteren bireyin, çabalarının sonucunun istihdam edilme ile sonuçlanması, diğerlerine göre daha olasidir.

İş arama sıklığının yanında, iş aramanın etkinliği de önemli bir rol oynamaktadır. İş arama davranışlarını sıkça tekrarlamak ya da yoğun bir şekilde iş aramanın her zaman olumlu sonuçlanmadığ 1 bilinmektedir. Örneğin, isabetli bir kişi ile görüşüp iş bulan bir 
kişinin yanında, o kadar isabetli olmayan daha fazla sayıda insan ile görüşüp halen iş bulamayanlar bulunmaktadir (Van Hoye vd., 2009: 675). Dolayısıyla sıklığın yanında, etkinlik de iş arama davranışını belirleyen bir kıstas olabilir.

\section{4. İş Arama Davranışının Sonuçları}

Doğru bir şekilde sürdürülen iş arama sürecinin en görünür olumlu sonucu bireyin bir iş teklifi alarak, istihdam edilmeye başlaması olarak düşünülebilir. Daha detaylı düşünüldüğünde ise, aslında iş arama davranışının sonucu olarak, son aşamaya gelen bireyin karşısında üç seçenek bulunmaktadır: 1) iş olanaklarından birini seçmek 2) birlikte çalıştığ 1 işvereni ile devam etmek (halihazırda çalışıyorsa) 3) işgücü piyasasından çekilmek (Rogelberg, 2007: 414).

İşaramayı, doğası gereği, süresi uzadikça, reddedilmelerle dolu ve dolayısıyla cesaret kırıcı, içinde belirsizlik barındıran bir süreç olarak düşünmek mümkündür. Daha önce de bahsedildiği gibi, özellikle işsiz birey için bu durum oldukça olumsuz etkilere sahiptir. Üzerinde bu gerginliği hisseden ve bir an önce iş bulması gerektiğini düşünen birey, bazen içine tam olarak sinmeyen, kendi vasfına göre daha düşük vasıf gerektiren bir pozisyonu kabul etmek zorunda kalmaktadır (McKee-Ryan, 2005: 58). İş arama davranışının pek de olumlu olmayan tarzda, bu şekilde sonuçlanması ileride, birey-iş uyumunu zedeleyerek, birey düzeyinde iş doyumsuzluğuna, makro düzeyde ise vasıf uyumsuzluğuna neden olabilecektir.

İş arama davranışının sonuçları ile aslında iş arama davranışının başarılı sayılabilmesi için hangi kriterlerin önemli olduğu üzerinde durulmaktadır. Bu konuda yapılan pek çok araştırmada, iş arama davranışının sonuçları olarak birbirinden farklı değişkenler kullanılmaktadır. Örneğin, girilen mülakat sayısı, alınan teklif sayısı, iş bulma hızı, bulunan iş ve örgütün kişiye uygunluğu, bulunan işin aranan işe uygunluğ $u$, bir önceki işten daha iyi bir iş bulup bulmama ve hatta iş doyumu ve iş değiştirme niyeti gibi istihdam edilme sonrası tutumlar üzerinde çalışmalar yapılmıştır (Başbuğ, 2008: 26). İş arama davranışı ve sonuçları arasında doğru orantılı bir ilişkinin gerçekleşebilmesi, bir diğer ifadeyle iş arama davranışının işi elde etme ile sonuçlanabilmesi genel olarak iş arama davranışının yoğun, aktif ve isabetli olarak yapılabilmesine bağlanabilir.

Modelde, yapılan iş görüşmesi ve teklif sayısı iş arama davranışının ilk sonuçları olarak düşünülmüştür. Bununla birlikte, iş görüşmesinin teklifi de etkileyeceği öngörülmektedir ancak Başbuğ (2008) çalışmasında görüldüğü gibi, işverenin görüşme yapmadan bireye teklif götürmesi gibi bir durumda, bu iki değişken arasında bir ilişki gözlenmemesi de söz konusu olabilir. İş görüşmesinde bulunan ve olumlu olması halinde iş teklifi alan bireyin, teklifi kendisi için uygun bulması durumu istihdam edilmeyle sonuçlanmaktadır.

\section{Sonuç}

İş aramak ve bulmak pek çok insan için oldukça zorlu bir iş olmakla birlikte, bu durum özellikle ekonomik krizlerin olduğu ve işsizliğin artış gösterdiği dönemlerde giderek zorlaşmaktadır. İşsizlik dünyamızdaki sosyal sorunların başında gelen, içinde pek çok boyut barındıran bir sorun olduğu için, bu sorunu farklı bilim dallarının bakış açısiyla incelemek gerekmektedir. Dolayısıyla iktisadi açıdan konuyu inceleyen çalışmaların yanı sıra, psikoloji ve sosyolojinin de katkılarıyla konunun farklı boyutlarını içinde barındıran, çözüme ilişkin iş arama ve bulmaya yardımcı olacak modellerin geliştirilmesi gerekmektedir.

İktisadi açıdan iş arama süreci, iş olanakları hakkında bilgi almak, edinilen bilgiye bağlı olarak işe başvurma kararı vermek ya da vermemek ve son olarak da kendisine gelen teklifi kabul etmekten oluşan üç aşamalı bir süreçtir (McFadyen ve Thomas, 1997: 1464). Fark edileceği gibi, psikolojik açıdan tanımlanan iş arama davranışında, bu sürecin ilk aşamasını oluşturan bilgi top- 
lamayı bireyin gerçekleştirme nedenleri ve bunu etkileyen faktörlerden bahsedilmektedir. Modelde, iktisadi açıdan üçüncü aşama istihdam edilme ile açıklanmaktadır. Ancak ikinci süreç olan işe başvurma kararı modelde yer almamıştır. İleride yapılacak olan iş arama davranışı araştırmalarında, bireyin iş arama sonucunda potansiyel olarak gördüğü bir işe başvurma kararı alıp almamasinda etkili olan faktörlere de dikkat çekilmesi önerilebilir. Modele ilişkin bir diğer kısıt, işgücünün farklı kesimleri olan işsiz ve çalışanlara özgü iki farklı alt-model sunulmamış olmasıdır. İleride yapılacak uygulamalı çalışmaların, kullanılacak örnekleme göre modeldeki değişkenleri, işsiz olup iş arayanlara göre veya çalışırken iş arayan bireylere uyarlaması önerilmektedir.

Bütüncül bir psiko-sosyal model önerisinde bulunulan bu çalışmada, iş aramaya yönelik teorilerden ve geliştirilmiş olan modellerden yararlanarak, iş arama davranışının öncülleri ve sonuçları hakkında açıklamalarda bulunulmuştur. İş aramanın bir süreç olarak başarılı bir şekilde yaşanabilmesi için pek çok faktörün bir araya gelmesinin gerekliliği bu modelde açıkça görülmektedir. Alanyazındaki çalışmalardan örnekler verilerek şekillenen bu modelin ülkemizdeki iş arama davranışı yazınına ve ayrıca modelde öne sürülen değişkenlerin kullanılacağ 1 uygulamalara katkısının olacağ1 düşünülmektedir. Makalenin iş arama ve bulma konusunda danışmanlık hizmeti veren uygulayıcılar için de önemli olduğu düşünülmektedir. Örneğin, bireysel özellikler açısından kişilik yapısının is arama davranışında etkili olduğu ve işsizliğin süresini belirlediği görülmektedir. Alınacak önlemlerde işsiz bireylerin kişilik değerlendirmeleri yapılıp, bireye olumlu bilişsel özelliklerin kazandırıldığ 1 ya da bunların geliştirildiği özdüzenleyici beceri eğitimleri verilmesi durumunda, bireyin doğru is arama davranışı göstermesi ve işgücü piyasasında kendi kişiliğine uygun bir iş bulması mümkün olacaktır. Özellikle devletin iş bulma kurumlarında işsizlere yönelik olarak verilecek, olumsuzluklarla baş edebilmek, bek- lentiyi yüksek tutabilmek için bilişsel yönden güçlendirici eğitimlerin, iş aramada 1srarc1 olma konusunda motivasyonu artıracağ 1 düşünülmektedir. Ülkemizde İşkur'un "İş ve Meslek Danışmanı" olarak istihdam edilecek bireylerin iş aramaya yönelik bu bilişsel güçlendirici eğitimleri vermek ve danışmanlıkta bulunmak üzere yetiştirilmesi önerilebilir. Ayrıca, iş arama konusunda net hedeflere sahip olmak, bireyin ne istediğine karar vermesi gerekliliğ $\mathrm{i}$, iş arama davranışını olumlu etkilediğinden, danışmanların bireye öncelikle, seçtikleri kariyer hakkında bilgi edinmeleri gerekliliğini tavsiye edip, sonrasında açık hedeflere sahip olmaları konusunda uyarıda bulunmaları başarılı bir iş arama süreci yaşamak adına önemlidir. 


\section{Kaynakça}

Avey, J. B., Luthans, F. ve Jensen, S. M. (2009). Psychological Capital: A Positive Resource for Combating Employee Stress and Turnover. Human Resource Management. 48(5), 677-669.

Bandura, A. (1997). Self-efficacy: The exercise of control. New York: Freeman.

Barber, A.E., Wesson, M.J., Roberson, Q.M., Taylor, M.S. (1994). Job Search Activities: An Examination of Changes Over Time. Personnel Psychology, 47(4): 739766.

Başbuğ, G. (2008). Üniversiteden Yeni Mezun Olan Gençlerin İş Arama Davranışlarının Planlı Davranış Teorisi Bağlaminda Araştırılması. İstanbul Üniversitesi Sosyal Bilimler Enstitüsü. Yayınlanmamış Yüksek Lisans Tezi.

Başbuğ, G. ve Elgin, C. (2010). The More Expecting to Have a Job, the More Having It. http:/ / www.econ.boun.edu.tr/public_html/RePEc/pdf/201010.pdf Erişim Tarihi: 02.01.2011.

Biçerli, K. (2000). Çalışma Ekonomisi. İstanbul: Beta Basım Yayım Dağıtım.

Bjornstadt, R. (2006). Learned helplessness, discouraged workers, and multiple unemployment equilibria. The Journal of Socio-Economics. 35: 458-475.

Blau, G. (1993). Further Exploring the Relatıonship Between Job Search and Voluntary Individual Turnover. Personnel Psychology. 46(2): 313-330.

Bora, T., Bora, A. Erdoğan, N. ve Üstün, İ. (2011). "Boşuna mı Okuduk?": Türkiye'de Beyaz Yakalı İşsizliği. İstanbul: İletişim Yayınları

Bretz, R.D., Boudreau, J.W., Judge, T.A.(1994). Job Search Behavior of Employed Managers. Personnel Psychology, 47(2): 275-301.
Brown, D. J., Cober, R. T., Kane, K., Levy, P. E. ve Shalhoop, J. (2006). Proactive Personality and the Successful Job Search: A Field Investigation with College Graduates. Journal of Applied Psychology. 91(3): 717-726.

Brown, P. ve Hesketh, A. (2004). The Mismanagement of Talent: Employability and Jobs in the Knowledge Economy. New York, NY: Oxford University Press.

Burdett, K. (1978). A Theory of Employee Job Search and Quit Rates. The American Economic Review. 68(1), 212-220.

Çakır, Ö. (2007). İşini kaybetme algısı: İş güvencesizliği. Çalışma ve Toplum. 1: 117140.

Caliendo, M. , Cobb-Clark, D. ve Uhlendorff, A. (2010). Locus of Control and Job Search Strategies. Deutsches Institut für Wirtschaftsforschung Discussion Papers No: 979.

Clifton, J. (2011). The War for Good Jobs. Gallup Management Journal. http: / / gmj.gallup.com / content/149144/Coming-Jobs-War.aspx Erişim: 07.09.2011.

Cote, S., Saks, A. M. ve Zikic, J. (2006). Trait affect and job search outcomes. Journal of Vocational Behavior. 68, 233-252.

Crossley, C.D. ve Stanton J.M. (2005). Negative affect and job search: Further examination of the reverse causation hypothesis. Journal of Vocational Behavior. 66: 549-560.

De Coen, A., Forrier, A. ve Sels, L. (2011). Job search intensity and wage flexibility among different age groups. Paper presented at the Academy of Management Meeting. San Antonio, Texas August, 2011. Available at https://lirias.kuleuven.be/bitstream / 123456789 / 322003/1/P\&O_1101.pdf. (21.12.2011). 
Doğan, S. ve Şahin, F. (2011). Yönetsel Güçlülük ve Etkililik: Kavramsal bir Çalışma. Atatürk Üniversitesi İktisadi ve İdari Bilimler Dergisi. 25(2): 61-85.

Erdogan, B. ve Bauer, T. N. (2011). The Impact of Underemployment on Turnover and Career Trajectories (İçinde) D.C. Maynard, D.C. Feldman (eds.), Underemployment: Psychological, Economic and Social Challenges (215-232). New York: Springer.

Feather, N. T., O'Brien, G. E. (1987). Looking for employment: An expectancy-valence analyses of job-seeking behaviour among young people. British Journal of Psychology. 78, s: 251-272.

Feather, N.T. (1992). Expectancy-value theory and unemployment effects. Journal of Occupational and Organizational Psychology. 65, s: 315-330.

Feldman, D. C. (2011). Theoretical Frontiers for Underemployment Research. (İçinde) D.C. Maynard, D.C. Feldman (Edi.). Underemployment: Psychological, Economic and Social Challenges. New York, NY: Springer, (s. 277-305).

Fleig-Palmer, M. M., Luthans, K. W. ve Mandernach, B. J. (2009). Successful Reemployment Through Resiliency Development. Journal of Career Development. 35(3): 228-247.

For Unemployed, Length, Scale of Job Search Affects Wellbeing. (2011). http:/ /www.gallup.com/poll/146345/ Unemployed-Length-Scale-Job-SearchAffects-Wellbeing.aspx (15.05.2011)

Fugate, M., Kinicki, A. J. ve Ashforth, B. E. (2004). Employability: A psycho-social construct, its dimensions, and applications. Journal of Vocational Behavior. 65, s: $14-38$.
Goldsmith, A. H., Veum, J. R. ve Darity, W. (1996). The psychological impact of unemployment and joblessness. Journal of Socio-Economics. 25: 333-358.

Holaday, M. ve McPhearson, R. W. (1997). Resilience and Severe Burns. Journal of Consueling and Development. 75: 346356.

ILO (2011). Global Employment Trends 2011: The challenge of a jobs recovery. Geneva: International Labour Organization.

Kağıtçıbaşı, Ç. (1999). İnsan ve İnsanlar. (10. Basım). İstanbul: Evrim Yayınevi.

Kanfer, R. ve Hulin. C. L. (1985). Individual Differences in Successful Job Searches Following Lay-Off. Personnel Psychology. 38: 835-847.

Kanfer, R., Wanberg, C. R. and Kantrowitz, T. M. (2001). Job search and employment: A personality motivational analysis and meta-analytic review. Journal of Applied Psychology. 86(5): 837-855.

Keeley, M. C. ve Robins, P. K. (1985). Government programs, job search requirements, and the duration of unemployment. Journal of Labor Economics. 3(3), s: 337-362.

King, J. E. (2000). White-collar reactions to job insecurity and the role of psychological contract. Implications for Human Resource Management. Human Resource Management. 39(1): 79-92.

Koen, J., Klehe, U. C. , Van Vianen, A.E. M., Zikic, J. ve Nauta, A. (2010). Job-search strategies and reemployment quality: The impact of career adaptability. Journal of Vocational Behavior. 77: 126-139. 
Kümbül-Güler, B. (2005). İşsizlik ve Yarattığ1 Psikososyal Sorunların Öğrenilmiş Çaresizlik Bağlaminda İncelenmesi. İstanbul Üniversitesi, İktisat Fakültesi Mecmuası (Prof.Dr. Toker Dereli'ye Armağan), 55 (1). İstanbul: İstanbul Üniversitesi, Yayın No: 4589, s: 373-394.

Kümbül-Güler, B. (2006). Çalışma Hayatında Öğrenilmiş Çaresizlik. Ankara: Liberte Yayınları.

Kümbül-Güler, B. (2009). Pozitif Psikolojik Sermaye: Tanımı, Bileşenleri ve Yönetimi. (İçinde) A. Keser, G. Yllmaz ve S. Yürür (Edi.) Çalışma Yaşamında Davranış: Güncel Yaklaşımlar (. Kocaeli: Umuttepe Yayınları.

Mavridis, D. (2010). Can Subjective WellBeing Predict Unemployment Length? The World Bank, Development Economics Vice Presidency, Operations \& Strategy Unit. Policy Research Working Paper 5293.

McFadyen, R. G. ve Thomas, J. P. (1997). Economic and Psychological Models of Job Search Behavior of the Unemployed. Human Relations. 50(12): 1461-1484.

McKee-Ryan, F. M., Song, Z., Wanberg, C. R. ve Kinicki, A. J. (2005). Psychological and Physical Well-Being During Unemployment: A Meta-Analytic Study. Journal of Applied Psychology. 90(1), s: 53-76.

Power, D. J. and Aldag, R. J. (1985). Soelberg's Job Search and Choice Model: A Clarification, Review, and Critique. The Academy of Management Review. 10(1), 48-58.

Rogelberg, S. G. (2007). Job Search. (İçinde) S.G. Rogelberg (Edi.). Encyclopedia of Organizational Psychology. California: Sage Publications, s: 414-416.
Rynes, S. L., Bretz, R. D. ve Gerhart, B. A. (1990). The Importance of Recruitment in Job Choice: A Different Way of Looking. Cornell University ILR School. Center for Advanced Human Resource Studies (CAHRS). Working Paper No: 389.

Saks, A. M. (2004). Job Search. Encyclopedia of Applied Psychology, Volume 2, 457.

Saks, A. M. (2005). Job Search Success: A Review and Integration of the Predictors, Behaviors, And Outcomes. (İçinde) S. D. Brown Ve R. W. Lent (Edi.) Career Development And Counseling: Putting Theory and Research to Work. Hoboken, NJ: John Wiley and Sons, Inc. (s: 155-179).

Schmit, M. J., Amel, E. L., ve Ryan, A. M. (1993). Self-reported assertive job-seeking behaviors of minimally educated job hunters. Personnel Psychology, 46, 105-124.

Steffy, B. D., Shaw, K. N. and Noe, A. W. (1989). Antecedents and consequences of job search behaviors. Journal of Vocational Behavior, 35, 254-269.

Unemployed Americans Face Challenging Job Search. (2011). http://www.gallup.com/poll/145817/unemployedamericans-face-challenging-job-search. aspx. (21.04.2011).

Uysal, S.D. ve Pohlmeier, W. (2010). Unemployment Duration and Personality. Paper submitted to Elsevier.

Van Hooft, E. A.J., Born, M. P., Taris, T. W. ve Van der Flier, H. (2004). Job search and the theory of planned behavior: Minority-majority group differences in The Netherlands. Journal of Vocational Behavior. 65: 366-390. 
Van Hoye, G. ve Saks, A M. (2008). Job search as goal-directed behavior: Objectives and methods. Journal of Vocational Behavior. 73: 358-367.

Van Hoye, G., van Hooft, E. A. J. ve Lievens, F. (2009). Networking as a job search behaviour: A social network perspective. Journal of Occupational and Organizational Psychology. 82: 661-682.

Wanberg, C. R., Kanfer, R. ve Banas, J. T. (2000). Predictors and outcomes of networking intensity among unemployed job seekers. Journal of Applied Psychology. 85(4): 491-503.

Wanberg, C. R., Watt, J. D. ve Rumsey, D. J. (1996). Individuals without jobs: An empirical study of job-seeking behavior and reemployment. Journal of Applied Psychology, Vol 81(1): 76-87.

Wanberg, C. R., Zhu, J. ve Van Hooft, E. A. J. (2010). The Job Search Grind: Perceived Progress, Self-Reactions, and Self-Regulation of Search Effort. Academy of Management Journal. 53(4): 788-807.

Wilson, C. D. (2007). Predictors of Job Search Behaviour in Canadian and Australian Undergraduate Students. University of Victoria Unpublished PhD Dissertation.

Zikic, J. ve Saks, A. M. (2009). Job search and social cognitive theory: The role of career-relevant activities. Journal of Vocational Behavior. 74: 117-127. 


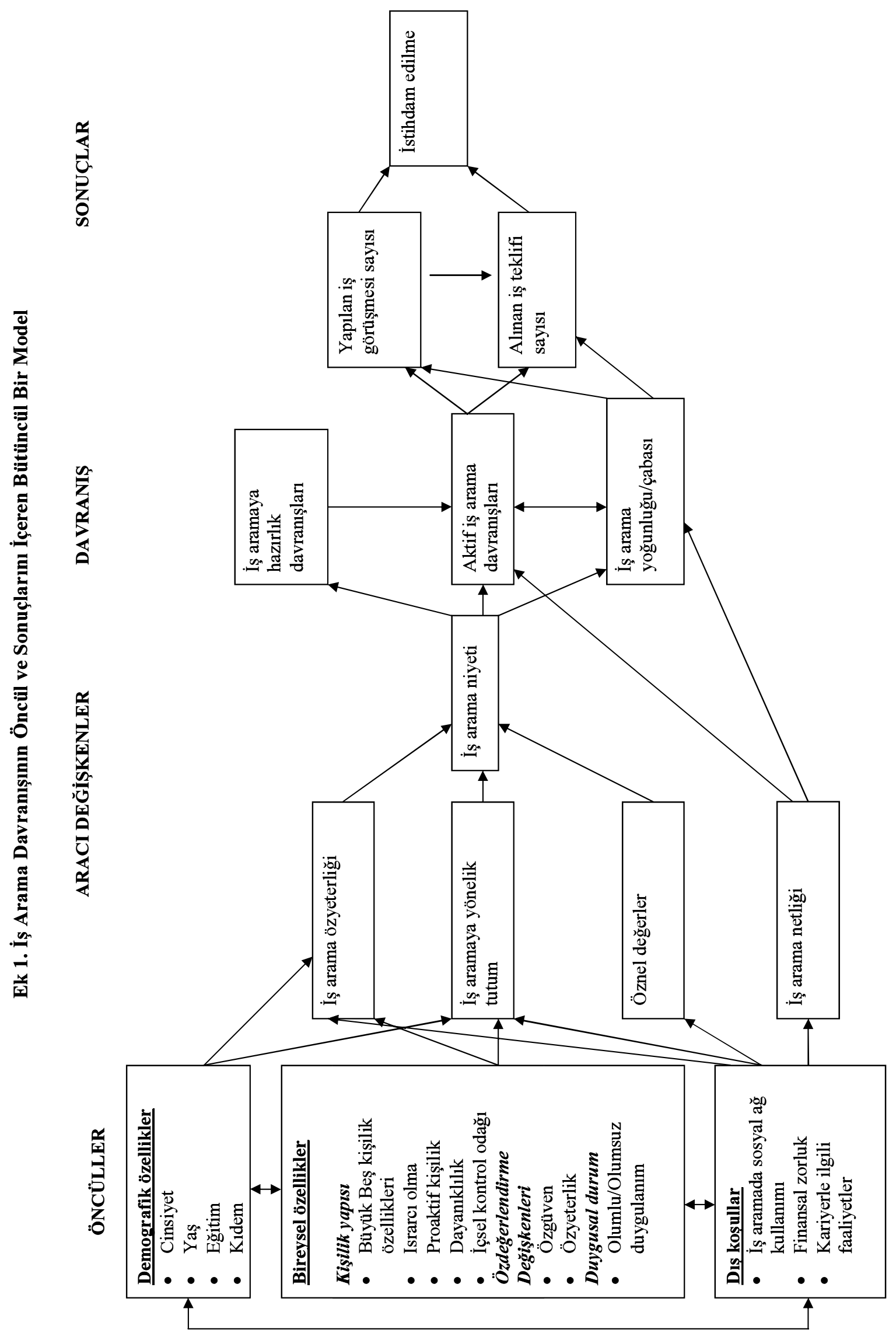

